\title{
Impact of Financial and Trade Openness on Financial Development in Oil and Non-Oil Developing Countries using the Panel ARDL Approach (With Emphasis on Institutional Components)
}

\author{
Bahram Sahabi ${ }^{1}$ \\ Mehdi Zolfaghari \\ Somayyeh Alavi ${ }^{3}$
}

\author{
sahabi_b@modares.ac.ir \\ m.zolfaghari@modares.ac.ir \\ somayyehalavi63@modares.ac.ir
}

\begin{abstract}
Given the importance of financial development to achieve sustainable economic growth, the main objective of this study is to investigate the effect of economic openness (financial and trade openness) on financial development (with emphasis on institutional components) in two groups of oil and non-oil developing countries. In this regard, the Panel ARDL method has been used for the period 2000-2017. The estimated results indicate a positive and significant effect of financial openness on financial development in the oil developing countries and its negative and significant impact on financial development of the non-oil developing countries in the long run. Also, the results show that trade openness has a significant and positive effect on financial development in non-oil developing countries in the long run. While the relationship of trade openness with financial development is statistically meaningless in the oil developing countries. Furthermore, most of the institutional variables in the developing countries have played a positive role in promoting the financial development index in the short-term and long-term. Nevertheless, the effect of these variables on financial development in the non-oil developing countries is very limited in the short-run while it is negative in the long-run.
\end{abstract}

Keywords: Financial Development, Financial Openness, Institutional Component, Trade Openness, Panel ARDL.

JEL Classification: F4, F31, F32, C1.

1. Associate Professor, Department of Economics, Tarbiat Modares University, Tehran, Iran.

2. Assistant Professor, Department of Economics, Tarbiat Modares University, Tehran, Iran (Author Correspondence).

3. M.A. in Economics, Tarbiat Modares University, Tehran, Iran. 


\section{تأثير باز بودن اقتصادى بر توسعه مالى كثورهاى در حال توسعه نفتى و غيرنفتى بازي

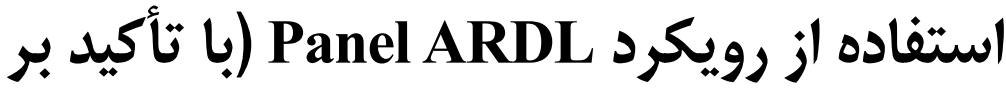

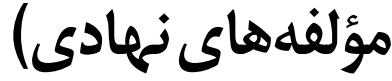

sahabi_b@modares.ac.ir

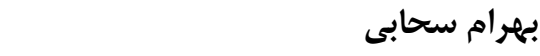
دانشيار كروه اقتصاد دانشكاه تربيت مدرس، تهران، ايران. m.zolfaghari@modares.ac.ir مهادى ذوالفقارى استاديار كروه اقتصاد دانشكاه تربيت مدرس، تهران، ايران. (نويسنده هسئول) somayyehalavi63@modares.ac.ir|

سميه علوى كارشناس ارشد كروه اقتصاد دانشكاه تربيت مدرس ، تهران، ايران.

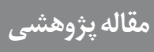

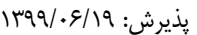

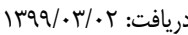
جكيده: با توجه به اهميت توسعه مالى در دستيابى به رشد پايدار اقتصادى، هدف محورى اين

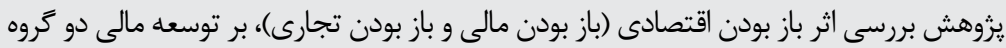

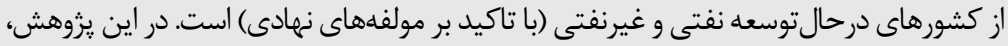

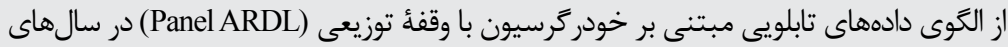

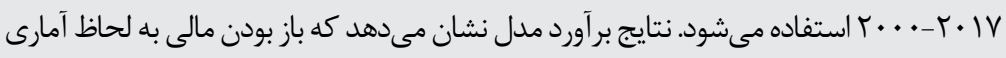

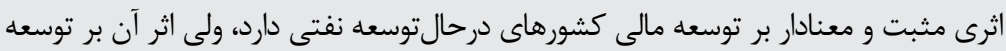

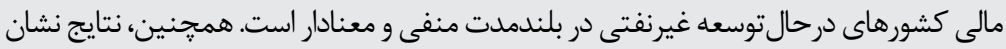

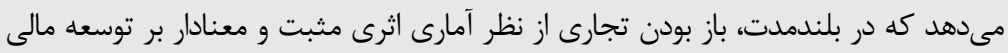

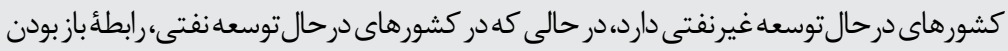

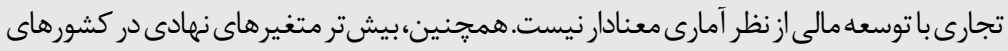

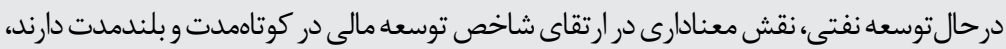

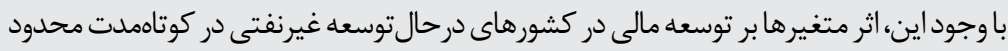
و ودر بلندمدت منفى است.

كليدوازهها: توسعه مالى، باز بودن مالى، مولفههاى نهادى، باز بودن تجارى، Panel ARDL. طبقهبندى F4, F31, F32, C1 :JEL. 
نظام مالى يك كشور از باز ارها، ابزارها، و محصولات مالى متنوع تشكيل مىشود. از منظر ديدگاههاى

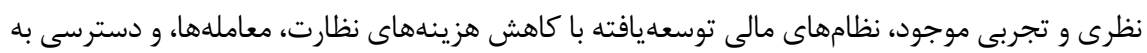

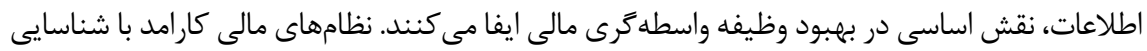
و تامين مالى فرصتهاى مناسب كسبو كار، تجهيز يساندازها، يوشش و متنوعسازى ريسك و همجنين تسهيل مبادله كالاو خدمات موجب گسترش فرصتهاى سرمايه گذارى ميىشوند. در ادبيات نظام مالى،

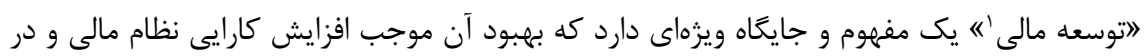

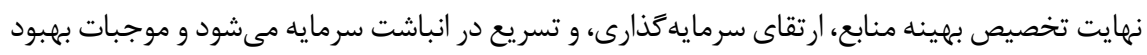

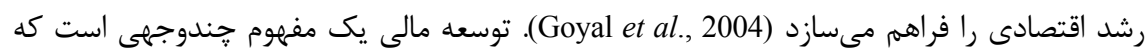

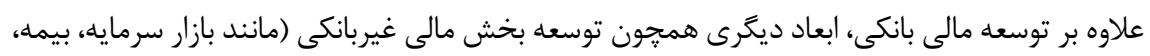

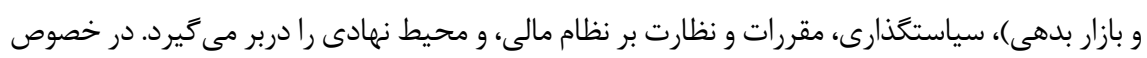

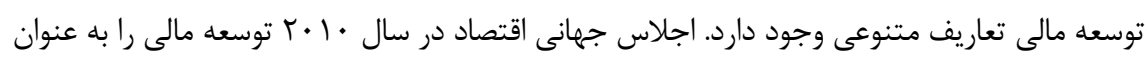

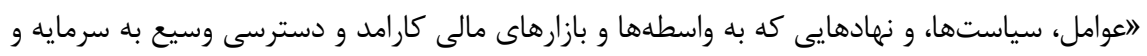

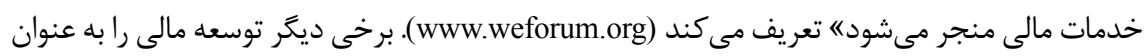
بهبود در كميّت، كيفيت، و كارايى خدمات واسطههاى مالى در نظر مى ميرند (Choong \& Chan, 2011).

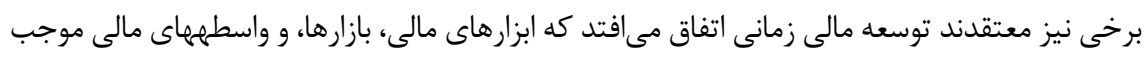
بهبود فرايند شفافيت اطلاعات، اقدامها، و هزينههاى مبادله شوند (Levine, 2005).

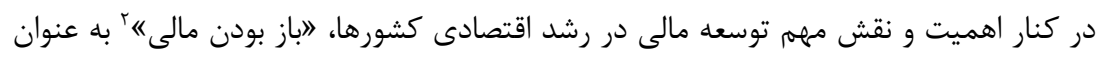

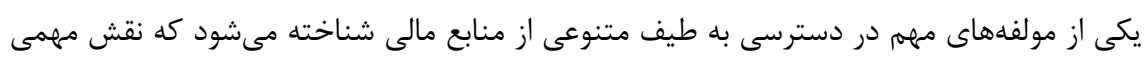

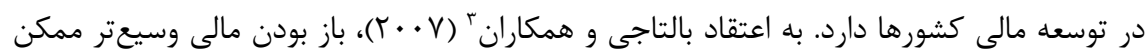
است نظام مالى اقتصاد را با ايجاد فضا براى تخصيص كاراتر سرمايه و سرمايهكذارى داخلى توالى تقويت

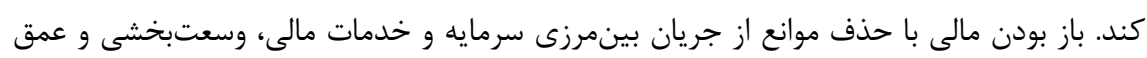

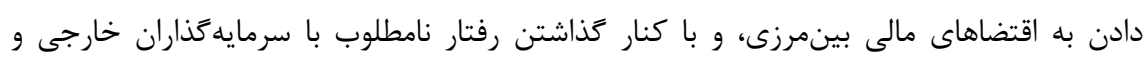

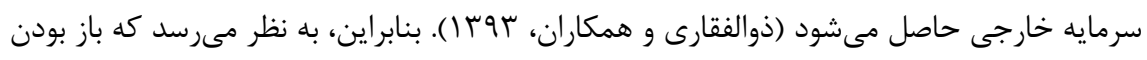

1. Financial Development

2. Financial Openness

3. Baltagi et al. 
مالى به عنوان يكى از متغيرهاى مهم اثر كذار بر توسعه مالى كشورها شناخته مىشود. به اعتقاد دو

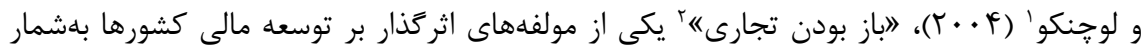
مىرود و يافتههاى ايشان نشان مىدهد كه توسعه مالى كشورها تا حدودى درونزاست و از تجارت تاثير مى يذيرد. برخلاف اقتصاددانان نئو كلاسيك، طيف وسيعى از اقتصاددانان نهادگرا معتقد هستند كه مولفههاى نهادى نقش بسزايى در توسعه مالى اقتصادها دارند. اين گروه از اقتصاددانان، علت إن

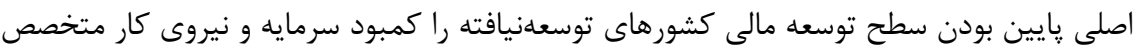
نمى دانند، بلكه نبود بستر نهادى مناسب براى فعاليتهاى اقتصادى مولد و انباشت سرمايه را عامل اصلى آن برمىشمارند. به موازات رويكرد اقتصاددانان نهادگرا، ادبيات اقتصاد سياسى جديد رشد

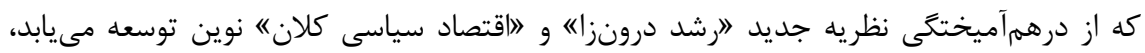
معتقد است كه عواملى نظير نظام سياسى، رفتار حاكمان، سياستهاى عمومى، فرهنگ، و مذهب از مههمترين عوامل نهادى اثرگذار بر رشد و توسعه اقتصادى و مالى جوامع محسوب مىشوند (عيسىزاده

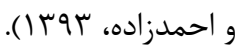

بررسى يزوهشهاى ييشين نشان از نبود يك اجماع در خصوص اثر باز بودن مالى و تجارى بر

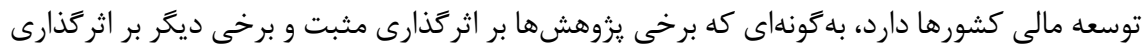
منفى متغيرهاى اشارهشده بر توسعه مالى اشاره دارند. در اين رابطه، با بررسى موشكافانه ادبيات

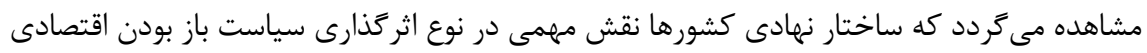
دارد و بررسى وضعيت متغيرهاى نهادى كشورها ضرورى است. از سوى ديگر، در بررسىهاى بخشى مشاهده مىشود كه باز بودن اقتصادى اثرهاى متفاوتى بر توسعه مالى بخشهاى ماى اقتصادى اعم از

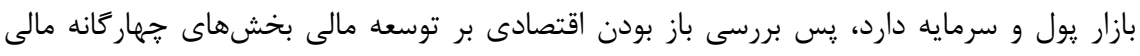

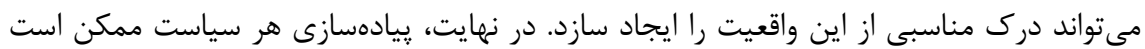
اثرهاى متفاوتى در كوتاهمدت و بلندمدت بر توسعه مالى داشته باشد، از اينرو بررسى جداكانه اثرهاى كوتاهدت و بلندمدت باز بودن اقتصادى بر توسعه مالى كشورها مىتوانند بر غناى ادبيات اين حوزه بيافزايد.

يزوهش حاضر به دنبال رفع شكافهاى اشارهشده است. در مقايسه با يزوهشهاى ييشين، يزوهش حاضر علاوه بر بررسى توسعه مالى از منظر كلى (اقتصاد كلان)، توسعه مالى را در جهار 
بخش مههم مالى اقتصاد يعنى بازار يول (بانك)، بيمه، سهام، و بازار بدهى مورد بررسى قرار مى دهد.

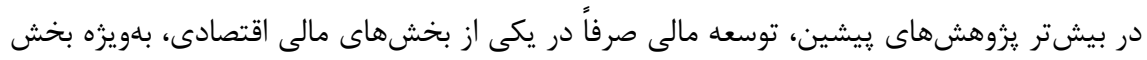
بانكى، مورد بررسى قرار مى گيرد. همجنين، در يزوهش حاضر از مولفههاى نهادى نيز استفاده مىشود

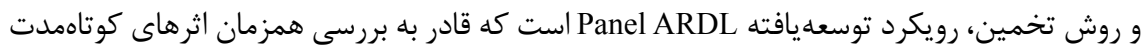
و بلندمدت متغيرهاى مستقل بر گروه جندمقطعى است، و از اين منظر بر مدلهاى فردى دادهـاى

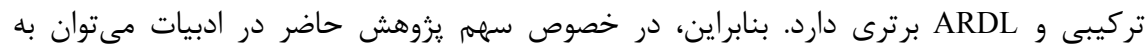

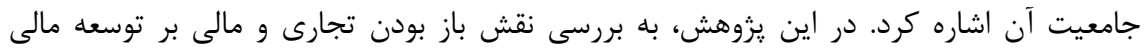

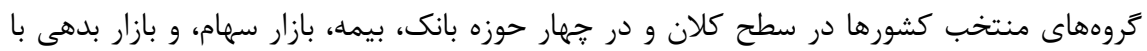

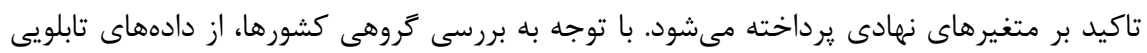

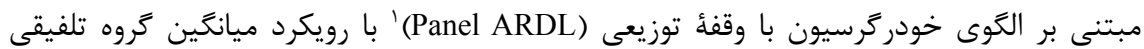
r(PMG)

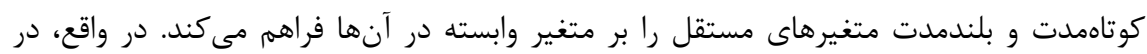
خصوص نحوه انتخاب مدل بايد بيان شود كه نظر به اين كه يزوهش حاضر به دنبال بررسى اثرهاى كوتاهمدت و بلندمدت باز بودن مالى و تجارى بر توسعه مالى دو گروه از كشورهاى منتخب است، مدل Panel ARDL

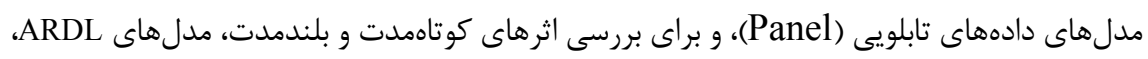
ابزار اقتصادسنجى مناسب هستند. براى دستيابى همزمان به دو هدف اشارهشده (بررسى اثرهاى كوتاهمدت و بلندمدت گروههاى جندمقطعى)، مدل Panel ARDL تامين كنندهُ اين دو نياز است.

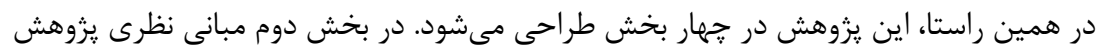

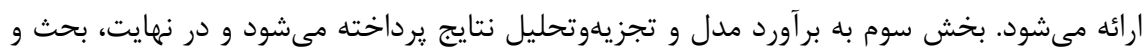

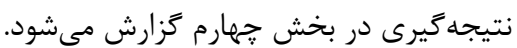

\section{مبانى نظرى يزوهش}

بهطور معمول، شاخصهاى توسعه مالى، ناظر بر جنبههاى توسعه در بخش بانكى و غيربانكى يا

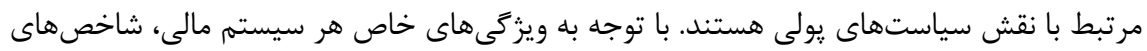


متفاوتى براى اندازهخيرى توسعه مالى معرفى مىشوند. بسيارى از يزوهشگران براى اندازهخيرى توسعه

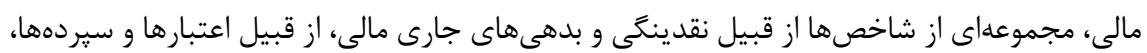
را به صورت درصدى از توليد ناخالص داخلى در نظر مى گيرند. در يروهش هاى ماى مختلف از شاخصهاى نسبت نقدينكى به توليد ناخالص داخلى، سهم اعتبارهاى تخصيصيافته به بخش غيردولتى از كل اعتبارها، نسبت سيردههاى موجود در بانكهاى غيردولتى به كل سيردههاى شبكه بانكى، و و سهم اعتبارهاى تخصيصيافته به بخش غيردولتى از توليد ناخالص داخلى به عنوان شاخصهاى

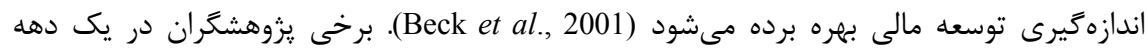

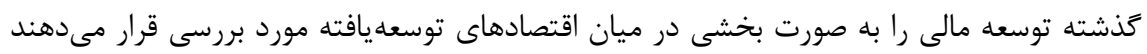
(Anwar et al., 2018)

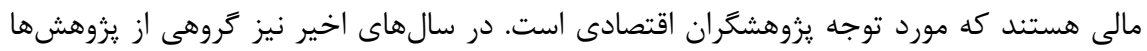

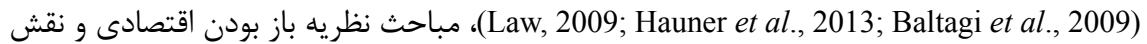

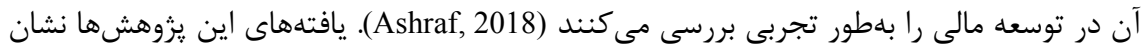
مى دهد كه باز بودن مالى امكان حضور كمهزينه سرمايهگذاران خارجى را در كشور فراهم مى كند و باز بودن تجارى موجب افزايش رقابتيذيرى بين بنگاههاى اقتصادى داخلى مىشود، كه با پديدار

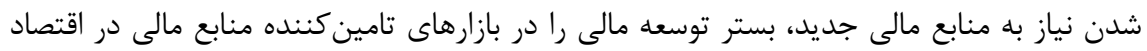

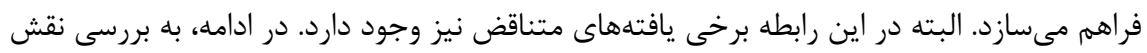

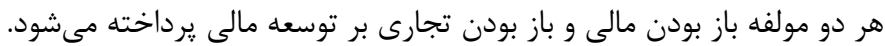
نظريه باز بودن مالى به رفع موانع سرمايهگذارن خارجى براى حضور در اقتصاد داخلى اشاره دارد. لوين' ( ( . ب)، بيان مى كند كه باز بودن مالى وسيع تر ممكن است نظام مالى اقتصاد را با ايجاد

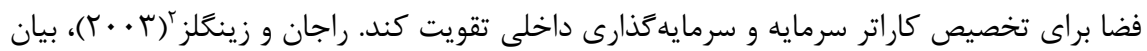
مى كنند كه باز بودن مالى ممكن است به نفع شركتهاى بزرى داخلى تمام شود، زيرا آنها اهرم

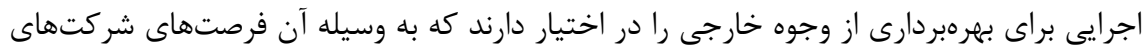

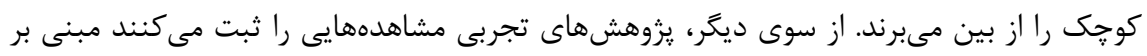

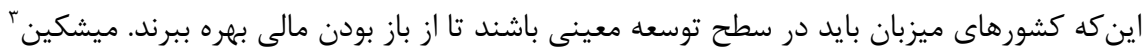

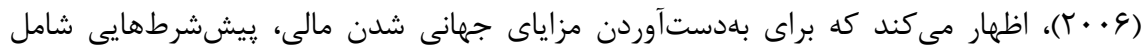

\section{Levin}

2. Rajan \& Zingales

3. Mishkin 
توسعهبخشى به حقوق مالكيت قوى، تقويت حاكميت شركتى، پايين آوردن فساد، و تقويت نظام قانون

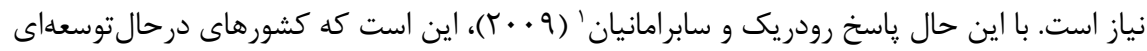
كه اين اصلاحات را با موفقيت مديريت كنند، زمان زيادى فقير نخواهند ماند و جهانى شدن مالى غيرضرورى خواهد بود. تاكنون، ادبيات جديد باز بودن مالى بيان مى كند كه مزاياى غيرمستقيم

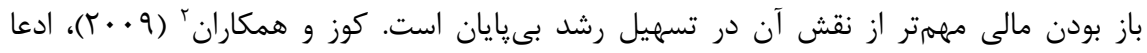
مى كنند كه جهانى شدن مالى مزايايى تضمينى يا به عبارتى اثرهاى غيرمستقيمى مانند توسعه

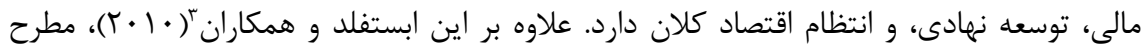

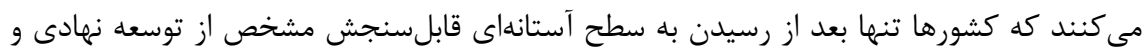

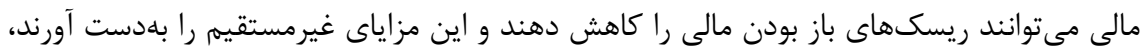

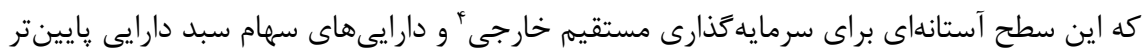

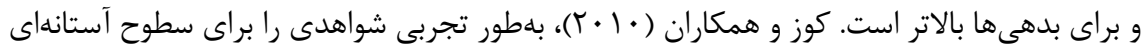

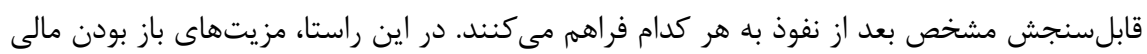
در دورههايى از رشد و جايكزينى هزينه و سود از باز بودن مالى، بهطور قابلملاحظهاى بهبود مى يابد

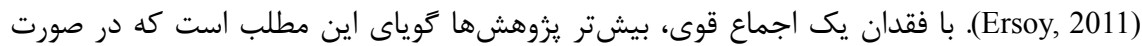

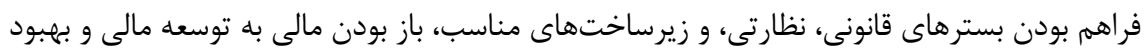
رشد اقتصادى منجر مىشود، در غير اين صورت نتايج ييادهسازى اين سياست نامطلوب است.

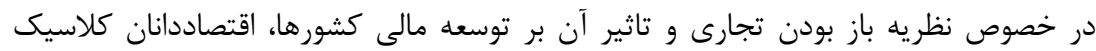

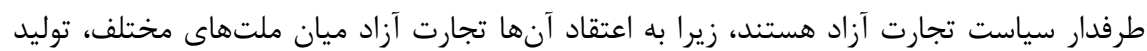

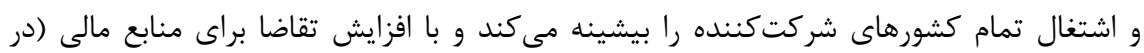

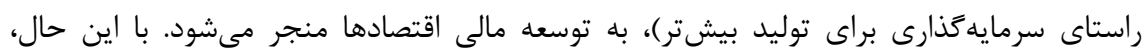

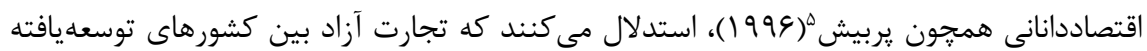

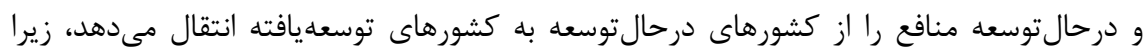
كشورهاى درحالتوسعه به كالاهاى اساسى وابستكى زيادى دارند، در حالى كه كشورهاى توسعهيافته

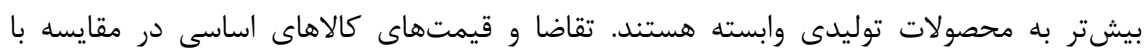

1. Rodrik \& Subramanian

2. Kose et al.

3. Obstfeld et al.

4. Foreign Direct Investment (FDI)

5. Prebish 
محصولات توليدى اغلب بيشتر است، بنابراين تجارت آزاد به كاهش دورهاى در تجارت كشورهاى درحالتوسعه منجر مىشود (Satyanarayana Murthy et al., 2014). با وجود اين، در خصوص تاثير نهايى باز بودن تجارى بر توسعه مالى و رشد اقتصادى، (همانند باز بودن مالى) اتفاقنظر جامعى وجود

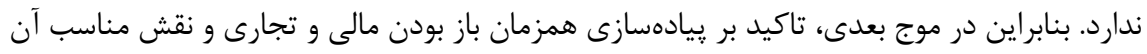

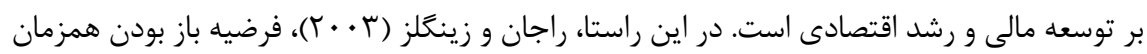

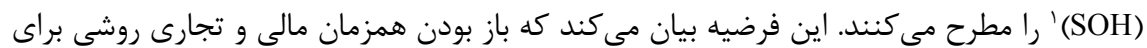

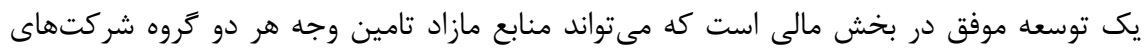

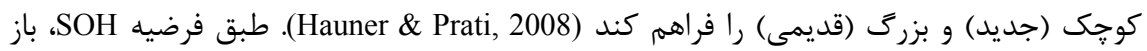

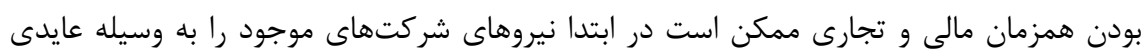

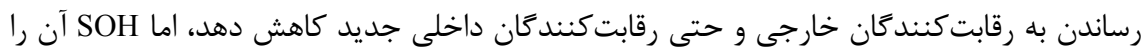
با منافعى بيش از آنجه ممكن است از دست داده باشند، جبران خواهد كرد (Baltagi et al. 2007). در بيشتر يزوهشهاى ييشين، يزوهشكران تاثير باز بودن مالى و تجارى را بر توسعه مالى كاه

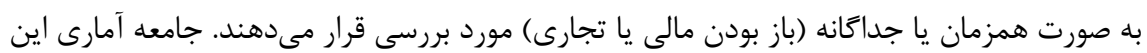
يزوهش ها به صورت گروهى از كشورها (يا كروهى از بانكها يا مناطق جغرافيايى در يك كشور) است

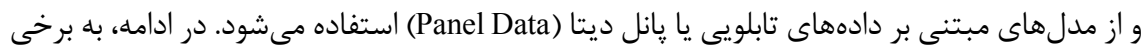

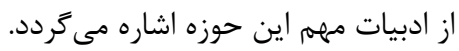

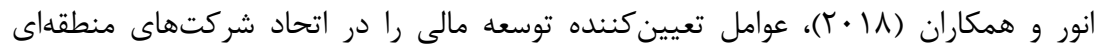
كشورهاى منتخب جنوب آسيا (SAARC) با استفاده از مدل يانل ديتا بررسى مى كنند. در اين

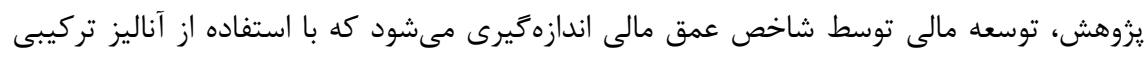

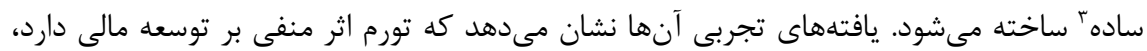
در حالى كه رشد اقتصادى، باز بودن تجارى، باز بودن مالى، نرخ ناخالص ثبتنام دوره دبيرستان،

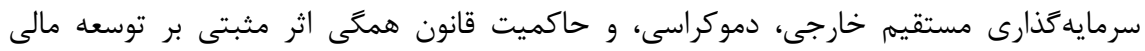

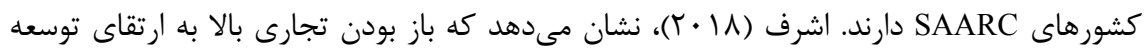

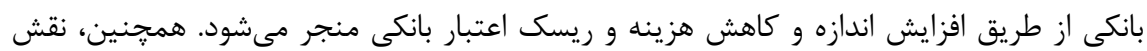

\section{Simultaneous Openness Hypothesis}


باز بودن مالى براى توسعه مالى در بخش بانكى محدود است. يافتههاى آبايومى و همكاران' (1 • (؟)، نشان مىدهد كه باز بودن تجارى با ناديده گرفتن سرمايه (يا برعكس) مىتواند براى توسعه مالى مالى كشور نيجريه زيانآور باشد. آنها با در نظر گرفتن اين مشاهده توصيه ميى كنند كه باز بودن همزمان تجارى و مالى يك روش تضمينشدهتر براى ييشرفت مطمئن توسعه مالى است. نتايج تجربى زانگ و و

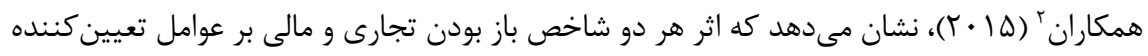
رقابت و كارايى مالى از نظر آمارى معنادار هستند، اما باز بودن بر اندازه توسعه مالى اثر منفى دارد.

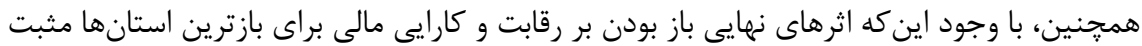

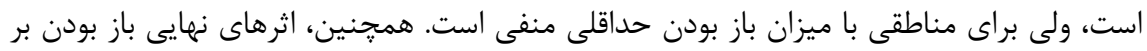

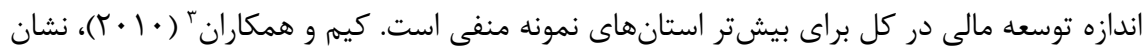

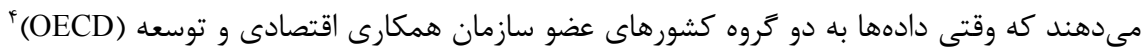
و غير OECD دستلبندى مىشوند، تاثير معنادار باز بودن تجارى بر توسعه مالى در كشورهاى غير

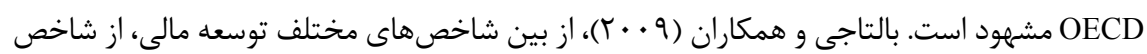

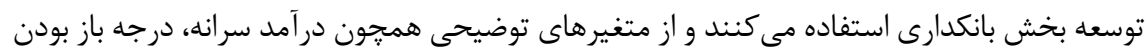

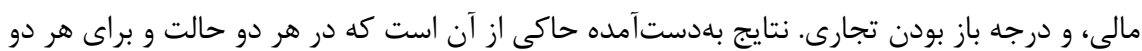

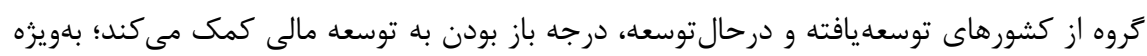

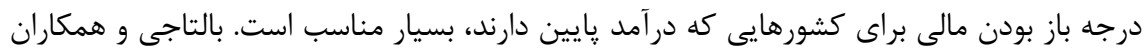

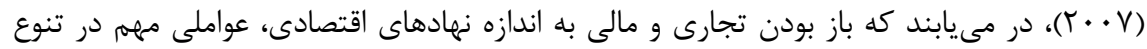
توسعه مالى بين كشورها از دهه • •191 به بعد هستند. با اين حال، حمايتى تلفيقى براى اين فرضيه

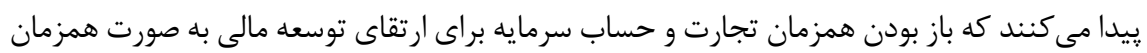

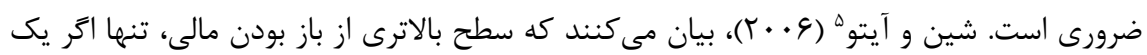
سطح آستانهاى از توسعه قانونى تامين شده باشد، به توسعه بازار سهام مى انجامد. بنا به موضوع ترتيب

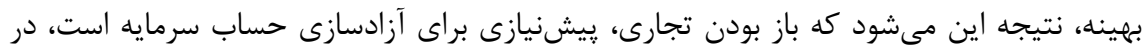
حالى كه توسعه سيستم بانكى بيششرط توسعه بازار سهام است.

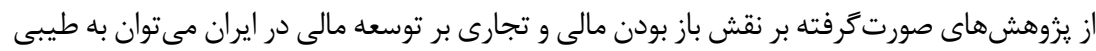

1. Abayomi et al.

2. Zhang et al.

3. Kim et al.

4. Organisation for Economic Co-operation and Development (OECD)

5. Chinn \& Ito 


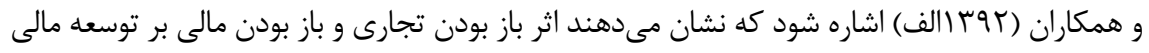

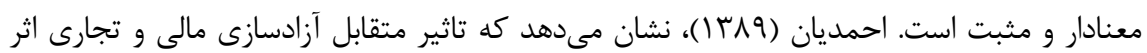

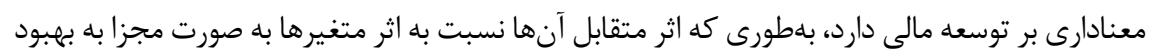

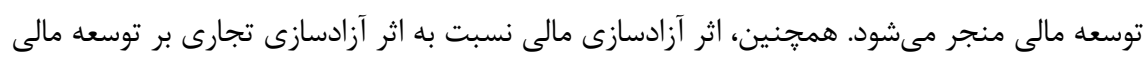

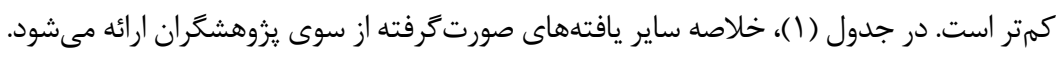

جدول ا: خلاصه يافتهاى بروهشهاى بيشين در خصوص تاثير باز بودن مالى و تجارى بر توسعه مالى

\begin{tabular}{|c|c|c|c|c|}
\hline خلاص & اقتصادسنجى مدل & مابسته & مستقل & نويسنده (سال) \\
\hline 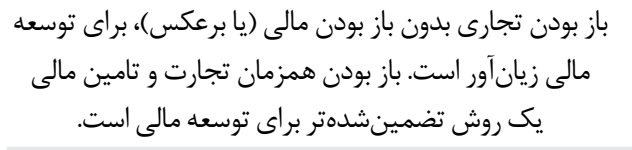 & تابلويى & توسعه & تجاز بون و & 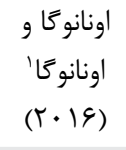 \\
\hline 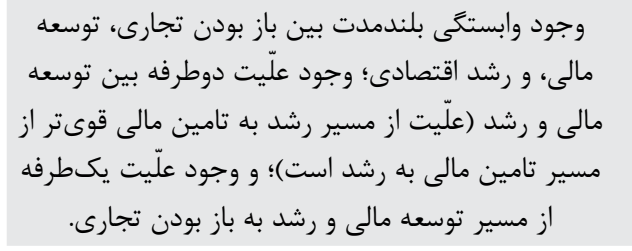 & مدل VAR & توسعه & باز بودن & ـ ـ مورتى و هاتيارايانا \\
\hline
\end{tabular}

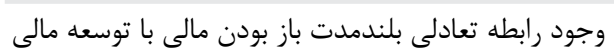

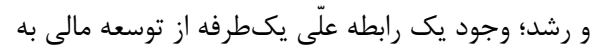

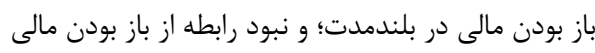

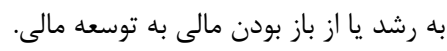

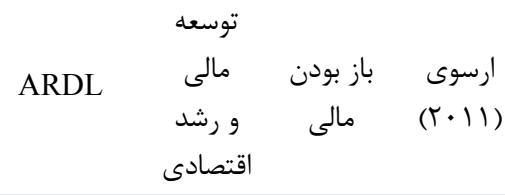

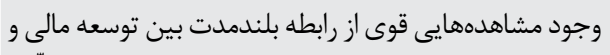

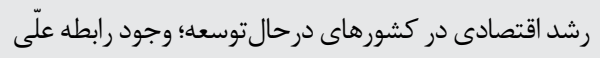

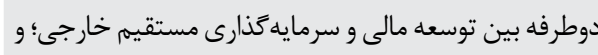

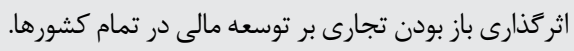

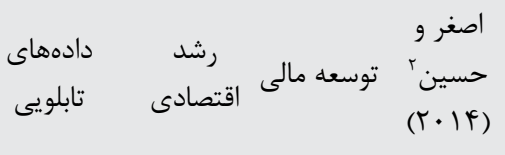

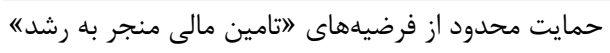

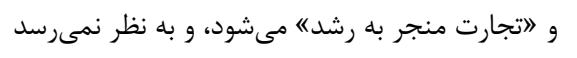

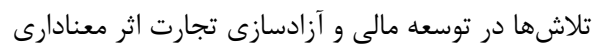
بر رشد داشته باشد.

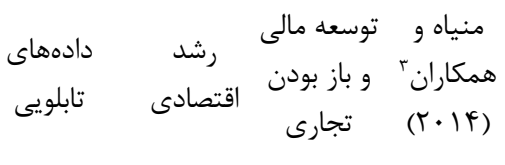

1. Onanuga \& Onanuga

2. Asghar \& Hussain

3. Menyah et al. 
ادامه جدول ا: خلاصه يافتهاى ثئوهشهاى بيشين در خصوص تاثير باز بودن مالى و تجارى بر توسعه مالى

\begin{tabular}{|c|c|c|c|c|}
\hline خلاصه نتايج & اقتصادسنجى مدل & وابسته & مستغير & نويسنده (سال) \\
\hline كشورهاى ثروتمند و وثبت تجارت بر رشد سيستم مالى در & تابلويى & توسعه & تجاز بودن & 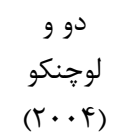 \\
\hline تورم اثر منفى بر عملكرد بازارهاى مالى دارد؛ و توليد & ARDL & توسعه & تورم & 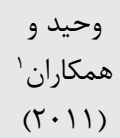 \\
\hline 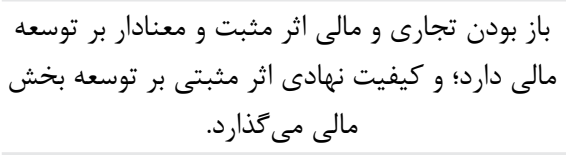 & تابلويى & توسعه & كاز بودن مارى، & مبلاجى \\
\hline 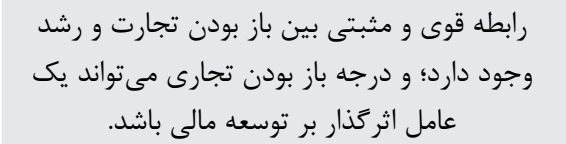 & تابلويى & مالى & تجارت و رشد بوند & $\begin{array}{l}\text { زيدى } \\
\text { و آبيداץ } \\
(r \cdot \mid r)\end{array}$ \\
\hline 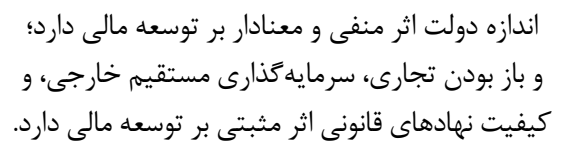 & تابلويى & توسعه & اندازه دولت، & و نانفروش ديزجى (I ) \\
\hline
\end{tabular}

\section{روش شناسى يزوهش}

با توجه به موارد اشارهشده، يزوهش حاضر به دنبال بررسى تاثير باز بودن مالى و باز بودن تجارى بر

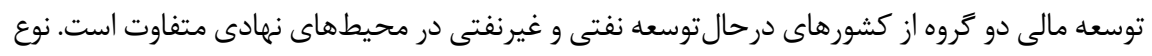

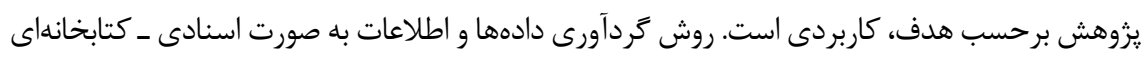

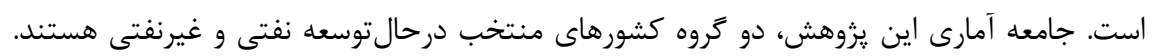

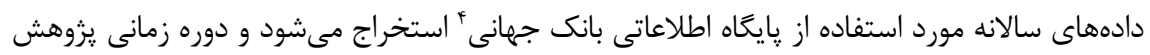

1. Wahid et al.

2. Asiama \& Mobolaji

3. Zghidi \& Abida

4. World Development Indicators (WDI) 


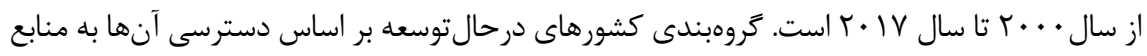
سرشار نفتى است. از اينرو در گروه كشورهاى نفتى، ها كشور درحالتوسعه مههم صادركننده نفت

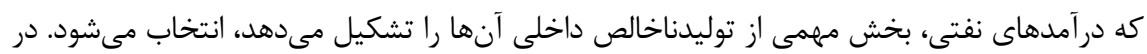

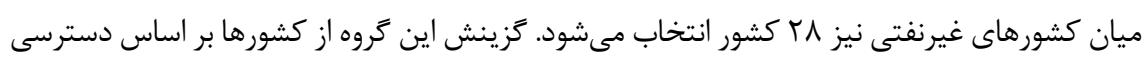

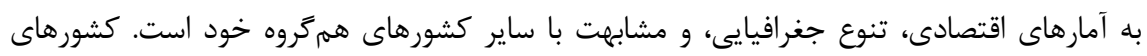

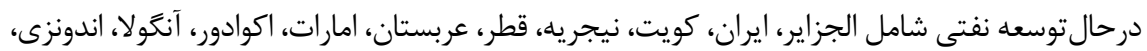
كابن، مكزيك، كلمبيا، ليبى، و عراق مىشود. كشورهاى درحالتوسعه غيرنفتى شامل تركيه، تايلند،

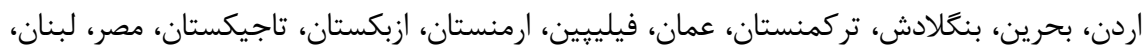

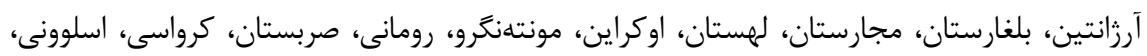

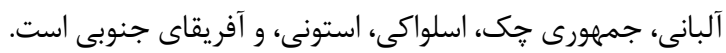

\section{Panel ARDL}

ساختار كلى مدل اقتصادسنجى با معادله پِانل يوياى خودرگرسيونى با وقفههاى توزيعى Panel ARDL $\left(\mathrm{p}, \mathrm{q}_{1}, \ldots, \mathrm{q}_{\mathrm{k}}\right)$

$y_{i t}=\sum_{j=1}^{p} \lambda_{i j} y_{i, t-j}+\sum_{j=0}^{q} \delta_{i j}^{\prime} X_{i, t-j}+\mu_{i}+\varepsilon_{i t}$

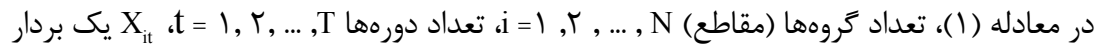

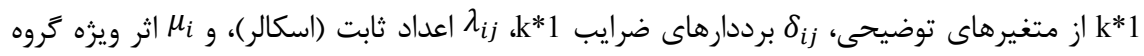

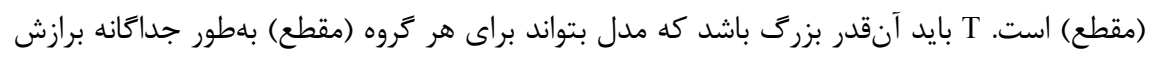

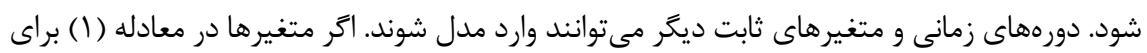

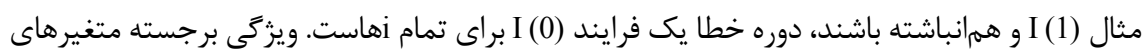

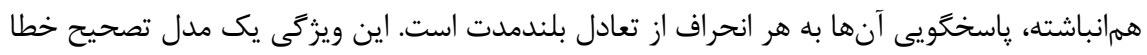

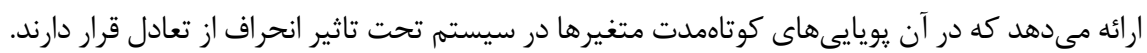
معمول است كه معادله (1)، به صورت معادله تصحيح خطا دوباره پارامترىسازى شود: $\Delta y_{i t}=\phi_{i}\left(y_{i, t-1}-\theta_{i}^{\prime} X_{i t}\right)+\sum_{j=1}^{p-1} \lambda_{i j}^{*} \Delta y_{i, t-1}+\sum_{j=0}^{q-1} \delta_{i j}^{l^{*}} \Delta X_{i, t-j}+\mu_{i}+\varepsilon_{i t}$

$\phi_{i}=-\left(1-\sum_{j=1}^{p} \lambda_{i j}\right)^{9} \quad \theta_{i}=\sum_{j=0}^{q} \delta_{i j} /\left(1-\sum_{k} \lambda_{i k}\right)^{9} \quad \lambda_{i j}^{*}=-\sum_{m=j+1}^{p} \lambda_{i m} \quad \mathrm{j}=1,2, \ldots, \mathrm{p}-1$

ir $\delta_{i j}^{*}=-\sum_{m=j+1}^{q} \delta_{i m} \quad \mathrm{j}=1,2, \ldots, \mathrm{q}-1$ 
يارامتر $\phi_{i}$ سرعت تصحيح خطاى دوره سازگارى را نشان مىدهد. اتر 0 = براى رابطه بلندمدت وجود ندارد. تحت فروض اوليهاى كه براى متغيرها براى برگشت به تعادل بلندمدت

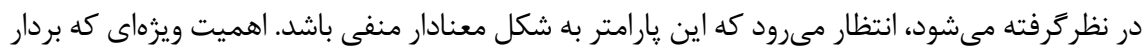

的

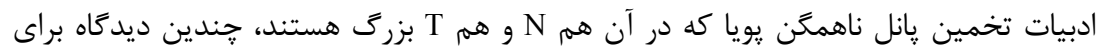
تخمين معادله (Y) بيان مى كند. يك ديدكاه افراطى، ديدگاه تخمين اثرهاى ثابت (FE) ' است كه در

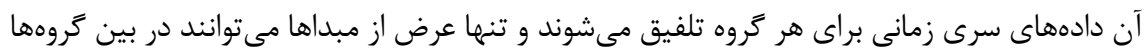

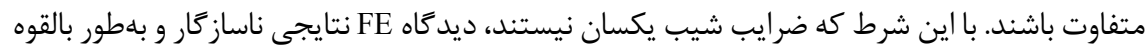
كَمراه كنندهاى را توليد مى كند. ديد كاه افراطى ديخر، مدلى است كه بتواند براى هر گروه بهطور جداكانه

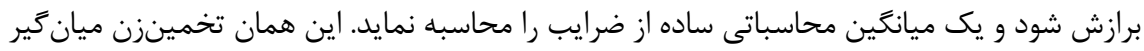
r (MG)

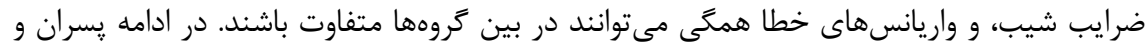

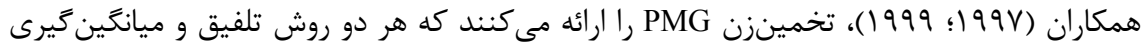
را با هم تركيب مىكند. اين تخمينزن كه بين دو تخمينزن قبلى قرار دارد، اجازه مىدهد كه

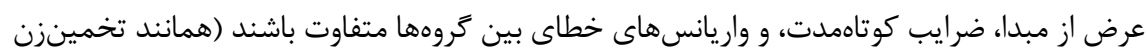

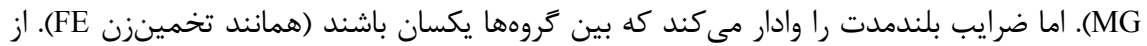
آنجايى كه معادله (r) در يارامترها غيرخطى است، پِران و همكاران (1999) يك روش بيشينه

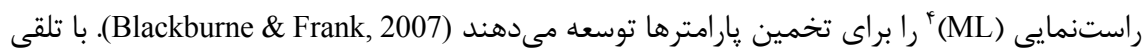

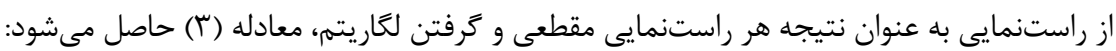

$l_{T}\left(\theta^{\prime}, \varphi^{\prime}, \sigma^{\prime}\right)=-\frac{T}{2} \sum_{i=1}^{N} \ln \left(2 \pi \sigma_{i}^{2}\right)-\frac{1}{2} \sum_{i=1}^{N} \frac{1}{\sigma_{i}^{2}}\left\{\Delta y_{i}-\phi_{i} \xi_{i}(\theta)\right\}^{\prime} H_{i}\left\{\Delta y_{i}-\phi_{i} \xi_{i}(\theta)\right\}$

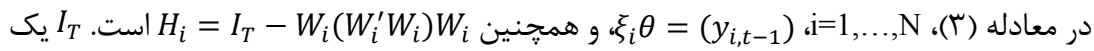

\section{Fixed-Effects (FE)}

2. Mean Group

3. Pesaran \& Smith

4. Maximum Likelihood 
ماتريس واحد از رتبه T است، و . . W.

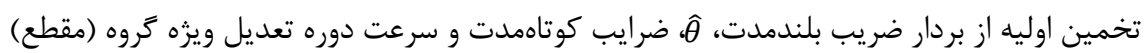

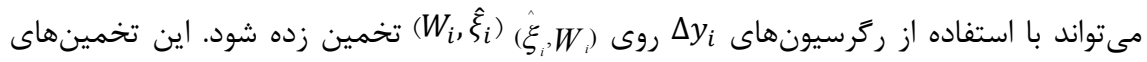
شرطى وظيفه تجديدسازى تخمين $\theta$ را به عهده دارند. اين فرايند تا زمان رسيدن به همگرايى ادامه

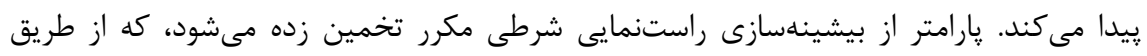

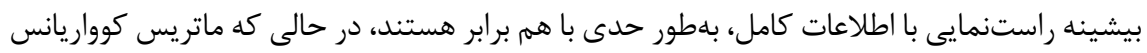
تخمينزدهده اين گونه نيست.

\section{تجزيهو تحليل مدل}

براى برآورد، مدل خودرگرسيونى با وقفه توزيعى (ARDL)، با استفاده از دادهاى تابلويى با

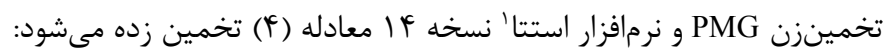
$Y_{i t}=\mu_{i}+\sum_{j=1}^{p} \lambda_{i j} Y_{i t-j}+\sum_{j=0}^{q} \delta_{i j}^{\prime} X_{i t-j}+\varepsilon_{i t}$

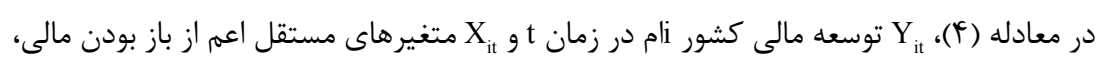

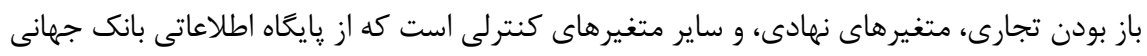

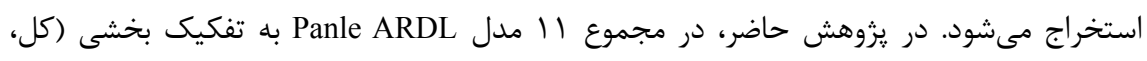

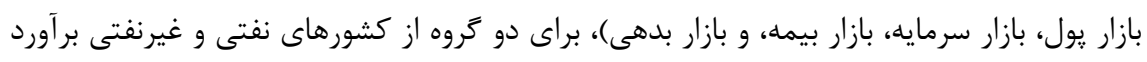

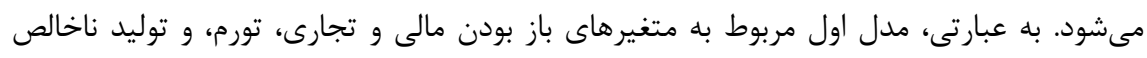

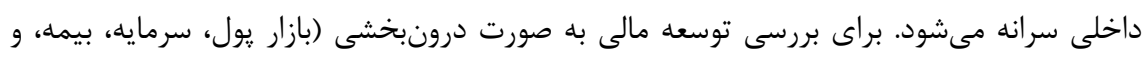

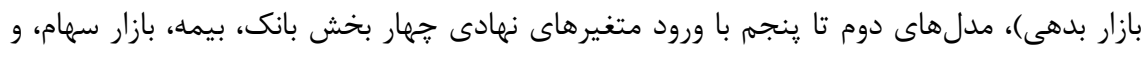

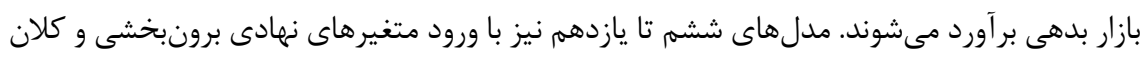
ارزيابى مىشوند. متغيرهاى وابسته و مستقل استفادهشده در برآورد اين مدلها بر بر اساس إدى ادبيات

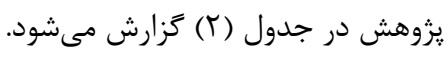




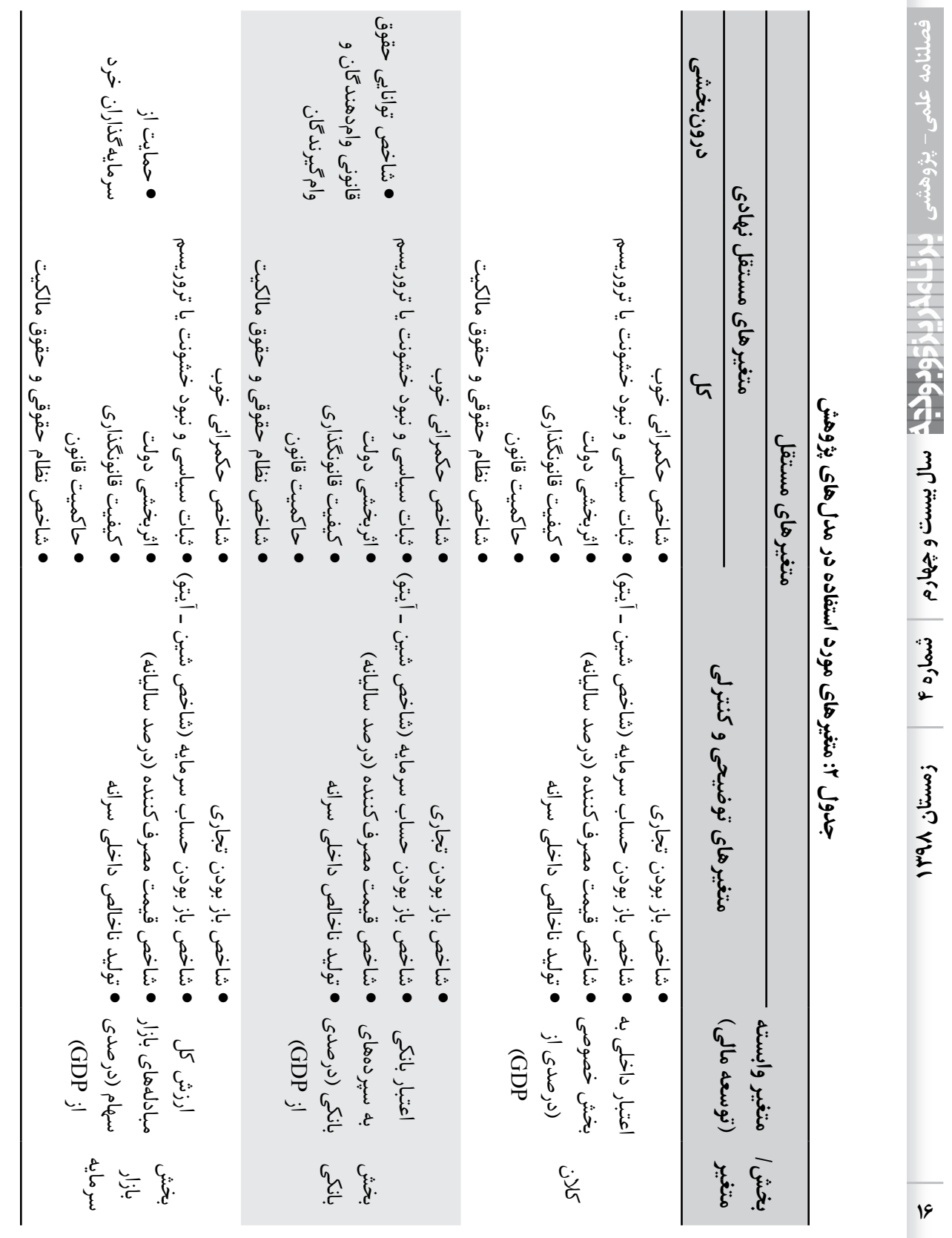




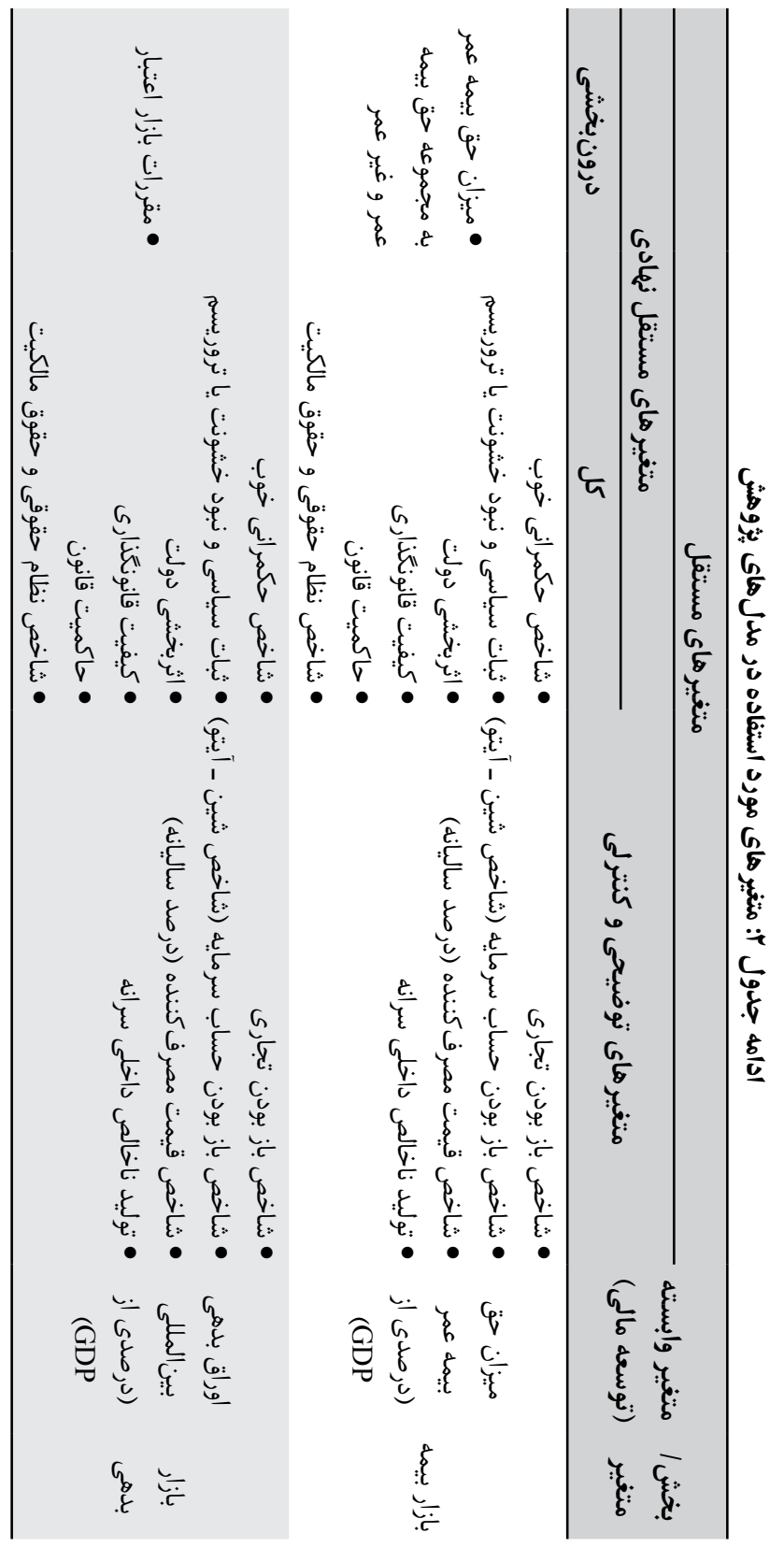


بر اساس جدول (Y)، شاخص باز بودن تجارى برابر است با نسبت مجموع صادرات و واردات به

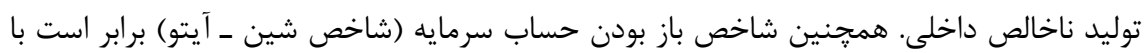
نسبت جريان كل ورود و خروج حساب سرمايه به توليد ناخالص داخلى كه به عنوان نماينده شاخص باز بودن مالى استفاده مىشود. همجنين، دو متغير شاخص قيمت مصرفكننده (درصد تغييرات)، و توليد ناخالص داخلى سرانه در كنار متغيرهاى نهادى به عنوان متغيرهاى كنترلى در نظرگرفته

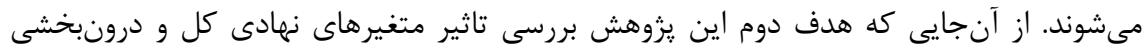

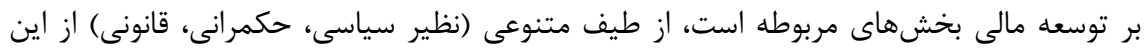

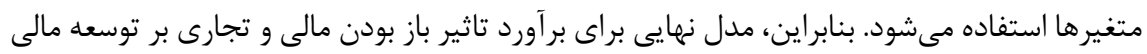

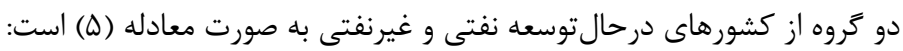
$F D_{i t}=a_{i}+\beta_{1} F O_{i t}+\beta_{2} T O_{i t}+\beta_{3} G D P_{i t}+\beta_{4} I N F_{i t}+\beta_{5} G I_{i t}+\beta_{6} P R_{i t}+\beta_{7} G E_{i t}++\beta_{8} P S_{i t}(\Delta)$ $+\beta_{9} L Q_{i t}+\beta_{10} R S_{i t}+\beta_{11} I I_{i t}+\varepsilon_{i t}$

در معادله (ه)، FD = شاخص توسعه مالى كشور i براى دوره t است. نياز به اشاره است كه بر اساس جدول (Y)، شاخص توسعه مالى در سطح كلان و در سطح بخشهاى مالى به تفكيك بر اساس مولفههاى معين (مبانى نظرى و يافتههاى تجربى) تعيين مىشود. FO = شاخص باز بودن مالى در كشور أ براى دوره

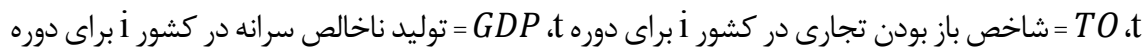
t t

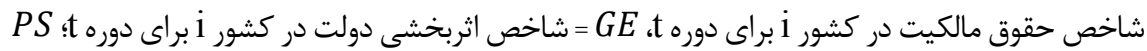

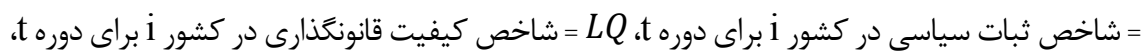

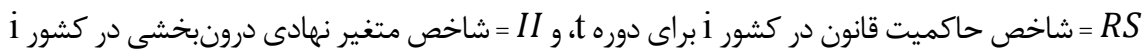
براى دوره t است. نياز به اشاره است كه همانند يزوهش هاى بيشين، براى بررسى دقيق اثر گذارى هر يك از

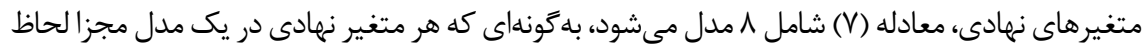

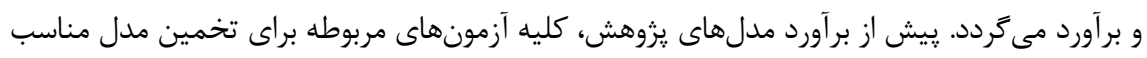
Panel ARDL تاكيد بر ارزيابى دو هدف اصلى يزوهش شامل بررسى اثر باز بودن تجارى و مالى بر توسعه مالى، و تاثير

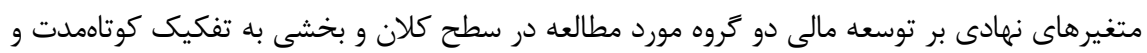

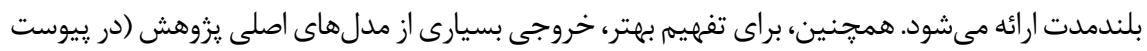

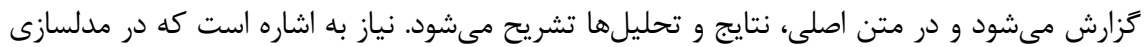

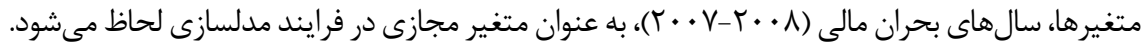




\section{اثرهاى كوتاهمدت و بلندمدت باز بودن مالى و باز بودن تجارى بر توسعه مالى}

با توجه به جدول (؟) در كوتاهمدت و در هر دو گروه كشورها، اثر باز بودن مالى بر توسعه مالى معنادار

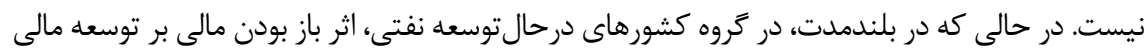

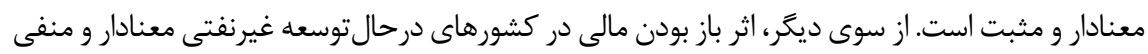

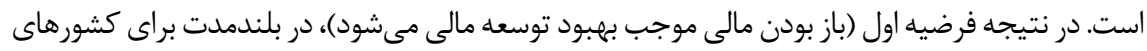
درحالتوسعه نفتى صادق است. با ملاحظه جدول (†)، در كوتاهمدت و در كشور هاى درحال توسعه غيرنفتى، باز بودن تجارى اثر معنادار و منفى بر توسعه مالى دارد، اما همين اثر در كشورهاى درحالتوسعه نفتى

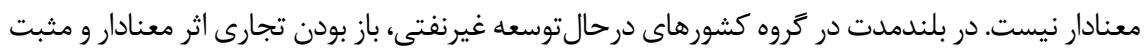

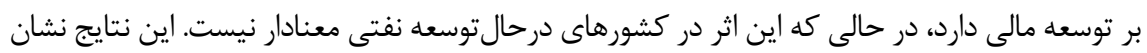

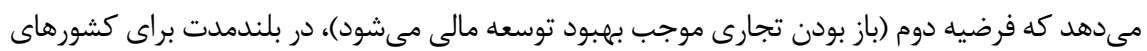

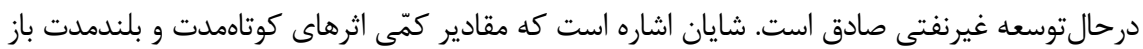
بودن مالى و باز بودن تجارى به همراه ساير متغيرهاى كنترلى در جداول ( () و (r) يِيوست ارائه مىشود.

جدول r: اثر كوتاهمدت و بلندمدت باز بودن مالى بر توسعه مالى

\begin{tabular}{|c|c|c|}
\hline كشور & درحال توسعه نفتى & درحال توسعه غيرنفتى \\
\hline كوتاهمدت & بىمعنا & بىمعنا \\
\hline بلندمدت & معنادار و مثبت & معنادار و منفى \\
\hline
\end{tabular}

جدول †: اثر كوتاهمدت و بلندمدت باز بودن تجارى بر توسعه مالى

\begin{tabular}{|c|c|c|}
\hline كشور ـ ـ دوره زمانى & درحال توسعه نفتى & درحال توسعه غيرنفتى \\
\hline كوتاهمدت & بىمعنا & معنادار و منفى \\
\hline بلندمدت & بىمعنا & معنادار و مثبت \\
\hline
\end{tabular}

بنابراين در يك نتيجه گيرى كلى مىتوان بيان داشت كه باز بودن مالى به توسعه مالى كشورهاى

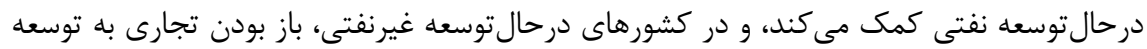

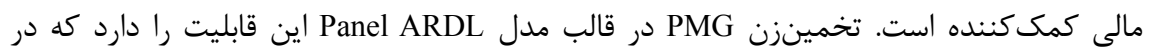


كنار ضرايب بلندمدت و كوتامدت براى دو گروه كشورها، ضرايب كوتاهمدت (و همجنين بلندمدت) متفاوت بين كشورها را برآورد كند. نتايج ضرايب كوتاهمدت دو متغير باز بودن مالى و تجارى بر بر توسعه

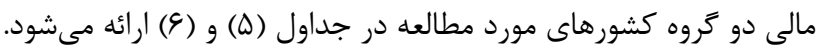

جدول ه: نتايج اثر كوتاهمدت باز بودن مالى (FO)، و باز بودن تجارى (TO)، بر توسعه مالى كشورهاى درحال توسعه غيرنفتى

\begin{tabular}{|c|c|c|c|c|c|c|c|c|c|}
\hline $\begin{array}{c}\mathbf{P}>|\mathbf{Z}| \\
\mathbf{E C M}\end{array}$ & $\begin{array}{c}\text { Z آماره } \\
\text { ECM }\end{array}$ & $\begin{array}{l}\text { ضريب } \\
\text { ECM }\end{array}$ & $\begin{array}{c}\mathbf{P}>|\mathbf{Z}| \\
\text { TO }\end{array}$ & $\begin{array}{c}\text { Z آماره } \\
\text { TO }\end{array}$ & ضريب & $\begin{array}{c}\mathbf{P}>|\mathbf{Z}| \\
\text { FO }\end{array}$ & $\begin{array}{c}\text { Z آماره FO } \\
\text { FO }\end{array}$ & ضريب & كشور \\
\hline$\cdot / \cdot \Delta V$ & $-1 / 9$. & - - /F\&s & r & $r / / r$ & $\cdot \mid \Delta \wedge \varepsilon$ & .11. & $1 / 94$ & $.1 \cdot 10$ & تركيه \\
\hline $.1 \cdot$ & $11 / 1 r$ & 1. & $\cdot / \cdot$ & $\Delta F / V V$ & $1 / 195$ & •/TAr & $-1 / \cdot V$ & $-\cdot / \cdot 1$ & تايلند \\
\hline . ITHF & $-1 / 19$ & $-\cdot / T V$. &.$/ 19$. & $1 / 4$. & $\cdot / r q$. & $\cdot / r \cdot q$ & $-1 / \cdot r$ & $-\cdot \cdot \cdot \mu_{1}$ & اردن \\
\hline$\cdot 1 \cdot$ & $-r / 9$. & $-1 / V \wedge$ & $\cdot 1 \cdot$ & $-Q / T T$ & $-\cdot$ Afts &.$/ \cdot$ qr & $T / \cdot T$ & $-\cdot / 1 \Delta \cdot$ & بحرين \\
\hline$\cdot / \cdot \Lambda r$ & $-1 / V F$ & $-/ A r \Delta$ & - /VTS & $-\cdot / r \Delta$ &.$- / 499$ & 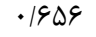 & $\cdot / 4 \Delta$ & $1 / \cdot r_{q}$ & بنحكلادش \\
\hline $.1 \cdot$ & $-r / \wedge 9$ & $-\cdot 19 \cdot r$ & $\cdot 1 \cdot \cdot 9$ & $-r / 9$. & $-\cdot / T M I$ & $\cdot / 1$. & $1 / 91$ & $\cdot / \cdot \wedge \wedge$ & تركمنستان \\
\hline.$/$ & $-r / 9 \Lambda$ & $-1 / \cdot \Delta 1$ & $\cdot / 149$ & $\cdot / \mathrm{VV}$ & $\cdot 1 \cdot 10$ & $\cdot / \cdot r q$ & $\Gamma / \Lambda \Lambda$ & ^ $9 / \% q$ & عمان \\
\hline$\cdot / 1 \Delta \Delta$ & $-1 / 4 T$ & - . AFT & $\cdot \mid \Delta F A$ & -.19. & $-\cdot / \pi \cdot 9$ & $\left.\cdot|\Delta|\right|^{f}$ & $-.19 \Delta$ &.$- / 1 r \Delta$ & فيلييين \\
\hline$\cdot / \cdot r$ & $-r / 11$ & $-\cdot|\Lambda| r$ & $\cdot / T \Delta Y$ & $-1 / 10$ & -.1949 & $\cdot / \mu \mid f$ & $1 / \cdot 1$ & $\cdot / \cdot r \Delta$ & ارمنستان \\
\hline$\cdot / I V \cdot$ & $-1 / T V$ & $-\cdot / r q 1$ & $\cdot / 1 \cdot r$ & $-1 / 94$ & $-1 /$ rध9 &.$/ \cdot \Delta F$ & $-1 / 94$ &.$- / 949$ & ازبكستان \\
\hline$\cdot 1 \cdot r$ & $-r / 10$ & -.1849 & שTr/. & $1 / T r$ & $.114 q$ & • & -.191 & $-\cdot 1 \cdot \vee \wedge$ & تاجيكستان \\
\hline$\cdot / \cdot \Delta G$ & $-1 / 91$ & אTRT & • & $-r / 99$ & $-1 / T \Delta F$ & $\cdot \cdot \cdot r$ & $r / \mu$ & $r / \cdot \Lambda \Lambda$ & مصر \\
\hline.$/ 1 r q$ & $-1 / \Delta Y$ & טזr/.- & $\cdot / T \Delta \varphi$ & $-1 / 1 f$ & $-\cdot|r \wedge|$ & $\cdot|V| \&$ & צא/. & .1 .99 & لبنان \\
\hline $.1 \cdot$ & $-r / \Delta \mid$ & $-\cdot / \vee q$. & $\cdot / 1 F \Delta$ & $-1 / 49$ & $-\cdot / \mu \cdot \cdot$ &.$|9| 0$ & $\cdot 10$. & T/9 & آرزانتين \\
\hline$\cdot 1 \cdot r \Delta$ & - & $-\cdot / 9 \cdot r$ & $\cdot \pi \cdot r$ & $-1 / \cdot r$ & $-\cdot \mid 1 \wedge 1$ & $\cdot / \cdot$ & $N / G F$ & או & بلغارستان \\
\hline$\cdot|r| 1$ & $-1 / 1 V$ &.$- / 1 \mathrm{~V}$. & . $/ F V K$ & $-\cdot / V r$ & $-\cdot / r \mid \Delta$ & $\cdot / \Delta \Delta q$ & $\cdot \mid \Delta \lambda$ & $.1 \cdot 19$ & مجارستان \\
\hline$\% r$ & $-r / \cdot \varphi$ & $-\cdot / V V V$ & $\cdot 1 \cdot Y q$ & $-Y / T Y$ & $-\cdot / r \Delta \Delta$ & $\|^{r}$ & $r / 91$ & $V / \Delta \omega$ & لهستان \\
\hline$\cdot 1 \cdot$ & $-1 \cdot 19$ &.$- / 9 F f$ & $\cdot / \cdot \nvdash \wedge$ & $1 / 91$ & $\cdot / 1 \wedge \Delta$ & $\cdot 1 \cdot V T$ & $1 / \Lambda$. & $|F / \Lambda| l^{F}$ & اوكراين \\
\hline$\cdot / \cdot r \Lambda$ & $-r / \cdot \Lambda$ & $-\cdot / r \wedge 9$ & $\cdot 11 \cdot 1$ & $1 / 90$ & $\cdot|r q|$ & $\cdot / \cdot r \Delta$ & $r / l \cdot$ & $r / \Delta \wedge \varphi$ & مونتهنگرو \\
\hline$\cdot 1 \cdot \cdot 1$ & $-r / \boldsymbol{T}$. & $-\cdot 191$. & $\cdot 19 \vee 9$ & $\cdot|f|$ & $\cdot 1 \cdot \operatorname{Ff}$ & $\cdot|q \wedge|$ & $\cdot|V|$ & .1 .98 & رومانى \\
\hline$\cdot 11 \cdot 9$ & $-1 / 9$. & $-\cdot / 4 \wedge q$ & $\cdot|f|$ & $-\cdot \mid A T$ & $-\cdot / T \& K$ & - IqAF & $\cdot|4|$ & $\cdot / \cdot \Delta f$ & صربستان \\
\hline . IFTY & $-\cdot / \lambda \cdot$ & - & . 194 & $.1 \cdot 9$ & $\cdot 1 \cdot \cdot 9$ & $\cdot / \mathrm{V} \backslash \Lambda$ & - & $-11 / F \wedge F$ & كرواسى \\
\hline
\end{tabular}


ادامه جدول ه: نتايج اثر كوتاهمدت باز بودن مالى (FO)، و باز بودن تجارى (TO)، بر توسعه مالى كشورهاى درحال تانوسعه غيرنفتى

\begin{tabular}{|c|c|c|c|c|c|c|c|c|c|}
\hline $\begin{array}{l}\mathbf{P}>|\mathbf{Z}| \\
\mathbf{E C M}\end{array}$ & $\begin{array}{c}\text { آماره } \\
\text { ECM }\end{array}$ & $\begin{array}{l}\text { ضريب } \\
\text { ECM }\end{array}$ & $\begin{array}{c}\mathbf{P}>|\mathbf{Z}| \\
\text { TO }\end{array}$ & $\begin{array}{c}\text { آماره } \\
\text { TO }\end{array}$ & $\begin{array}{c}\text { ضريب } \\
\text { TO }\end{array}$ & $\begin{array}{c}\mathbf{P}>|\mathbf{Z}| \\
\text { FO }\end{array}$ & $\begin{array}{c}\text { Z آماره } \\
\text { FO }\end{array}$ & ضريب & كشور \\
\hline$\cdot 1 \cdot$ & $-\Delta / 99$ & $-\cdot 19 \cdot 9$ & $|r|$ & $-1 / \Delta 1$ & -.1 .91 & .1 .49 & $1 / 9 V$ & $\cdot 1 \cdot r \Delta$ & اسلوونى \\
\hline$\cdot 1 \cdot$ & tr & -.1911 & $\% r$ & $-r / 11$ & $-1 / V 99$ & $\cdot / \cdot V$ & $r / 99$ & ITrV & آلبانى \\
\hline $.1 \cdot T V$ & $-T / T)$ & $-\cdot \mid 9 \Delta \cdot$ & $\cdot \mid 9 \wedge 9$ & $\cdot / 4$. &.$/ 1 V 9$ & .1911 & $-\cdot|\Delta|$ & $-.1 \cdot 19$ & جمهورى جك \\
\hline$\cdot|\cdot| f \mid$ & $-r / \cdot F$ & $-\cdot|k| T$ & $\cdot / \vee \wedge$. & $-\cdot / r \wedge$ & $-\cdot /$ rᄉr & • 19^r & $\cdot|4|$ & $\Delta / \cdot V \nabla$ & اسلواكى \\
\hline.$/$ & $-\Upsilon / 99$ & $-1 / \cdot+\wedge$ & $\cdot / T V R$ & $-1 / 1$ & $-\cdot / K M F$ & - ITVE & $1 / \cdot 9$ &.$/ I T V$ & استونى \\
\hline.$/ \cdot$ & $-\varphi / \cdot \Delta$ & $-1 / T / K$ & $\cdot 1 \cdot \wedge f$ & $-1 / V r$ & $-\cdot / r \vee q$ & $\cdot 10 \cdot r$ & $-.19 V$ & $-\cdot / \cdot r \Lambda$ & آفريقاى جنوبى \\
\hline
\end{tabular}

جدول \&: نتايج اثر كوتاهمدت باز بودن مالى (FO)، و باز بودن تجارى (TO)، بر توسعه مالى كشورهاى درحال توسعه نفتى

\begin{tabular}{|c|c|c|c|c|c|c|c|c|c|}
\hline $\begin{array}{c}\mathbf{P}>|\mathbf{Z}| \\
\mathrm{ECM}\end{array}$ & $\begin{array}{l}\text { Z آماره ECM } \\
\text { ECM }\end{array}$ & ضريب & $\begin{array}{c}\mathbf{P}>|\mathrm{Z}| \\
\text { TO }\end{array}$ & $\begin{array}{c}\text { آماره } \\
\text { TO }\end{array}$ & ضريب & $\begin{array}{c}P>|Z| \\
\text { FO }\end{array}$ & $\begin{array}{c}\text { آماره } \\
\text { FO }\end{array}$ & ضريب & كشور \\
\hline$\cdot 1 \cdot$ & $-\Lambda / \cdot \Lambda$ &.$- / 9 \vee 8$ & $.199 \mathrm{~V}$ & $\cdot 1 \cdot$ & $\cdot|\cdot \cdot|$ & $\cdot / 1 \cdot 1$ & $-1 / 8 \wedge$ & $-\cdot / r q V$ & الجزاير \\
\hline .1 .91 & $-1 / A V$ & $-\cdot / T \Delta F$ & - $19 \Lambda$. & $\cdot|4|$ & $\cdot / 1 \cdot 1$ & $\cdot / T V T$ & $-1 / 1$ & $-\cdot \mid \cdot r l$ & ايران \\
\hline$\cdot \pi \& \Delta$ & -.191 & $-\cdot / I T \Lambda$ & $\cdot / \cdot \Delta V$ & $-1 / 9$. & $-\cdot / V \Delta F$ &.$/ D F q$ & $-\cdot 19$ &.$- / 1 F \wedge$ & كويت \\
\hline . IITF & $-1 / \Delta F$ & מr/אמ & $\cdot 19 \cdot \Delta$ & $-\cdot / D T$ & $-\cdot / K I V$ & . IGVT & . AT & .1 .19 & نيجريه \\
\hline.$/$ & $-r \varepsilon \mid \cdot 1$ &.$- / 9 \& 4$ & $\cdot 1 \cdot \Delta 9$ & $-1 / 19$ & -.1 .99 & . &.$|9|$ & $.1 \cdot \cdot 9$ & قطر \\
\hline$\cdot 1 \cdot \cdot r$ & $-\Gamma / \| r$ & - & צTr/. & $-\cdot / 91$ & $-\cdot / 19 \wedge$ &.$/ 94 \wedge$ & $\cdot 1 \cdot V$ & $\cdot / \cdot r$ & عربستان \\
\hline $.1 \cdot$ & $-r / \wedge \Delta$ & $-\cdot / 9 \cdot V$ & $.1 \cdot$ & $-r / 9 F$ & $-1 / A V F$ & $\cdot \mid \Delta \wedge \hat{F}$ & $-\cdot / \Delta \Delta$ & $-8 / \cdot r q$ & امارات \\
\hline . I. FT & $-r / \cdot r$ & - • KG & - ITFV & $-1 / 19$ & - & - $\mid \wedge \wedge \&$ & $-\cdot / 1 F$ & $-\cdot \mid \cdot \cdot 1$ & اكوادور \\
\hline .1 & $-\Delta / 9 \Lambda$ & $-\cdot / V V T$ & $.1 \cdot 11$ & $-r / \Delta \Delta$ & $-\cdot / V k$ &.$/ 9 F V$ & $\cdot / \cdot V$ & I/ITA & آنكولا \\
\hline $.1 \cdot$ & |r/r|r & $-.1 .9 T$ & $.1 \cdot$ & $\Delta F / T G$ & $r / T \Delta V$ & .1919 & $\cdot 10$. & $\cdot / \cdots 1$ & اندونزى \\
\hline.$/ \cdot T V$ & $-r / T I$ & $-\cdot / 4 \& 9$ & - $/ \vee \wedge \Delta$ & $\cdot / T V$ & $\cdot / T / \Delta$ & - $|A F|$ & $-\cdot / r$ & $-\cdot / \cdot \cdot r$ & كابن \\
\hline .1 & $-\Delta / V \mid$ & $-\cdot \mid \Delta \Delta F$ & $\cdot 1 \cdot$ & $r / \Delta \Gamma$ &.$/ 1 \vee q$ & $\cdot 1 \cdot$ & $F / 1 r$ & $\cdot / 1 \cdot r$ & مكزيك \\
\hline $.1 .9 \mathrm{~V}$ & $-1 / \lambda r$ &.$- M F T$ & . /VG. & $-\cdot|r|$ & $-\cdot / \mu \wedge \varepsilon$ & $\cdot / r \cdot V$ & $1 / \cdot r$ & $\| r \mid / F$ & كلمبيا \\
\hline .1 .99 & $-1 / \lambda F$ & $-\cdot / r V r$ & $\cdot \mid \Lambda \ldots$ & $-\cdot / r \Delta$ & $-\cdot|r| \Lambda$ & .19 .9 & $-\cdot / 11$ & $-1 r / v q$ & ليبى \\
\hline$\cdot|\cdot|$ & $-r / r \Lambda$ & $-\cdot 1 \Delta \& 9$ & $\cdot \mid \cdot \vee 1$ & $1 / \lambda$. & $\cdot / 1 \cdot V$ & . & $\cdot 199$ & $\cdot / \cdot \Delta r$ & عراق \\
\hline
\end{tabular}


بررسى جداول (ل) و (9) نشان مىدهد كه در كروه كشورهاى درحالتوسعه غيرنفتى، باز

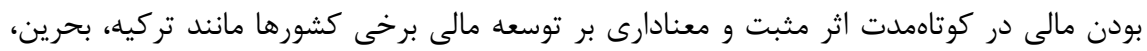

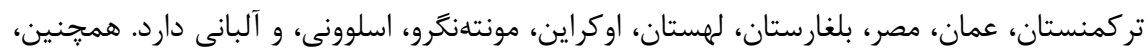

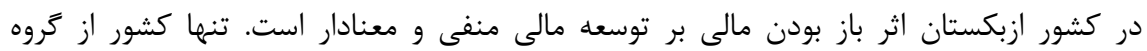

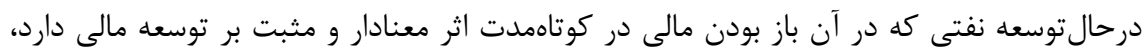

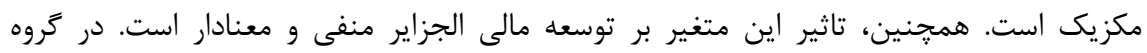

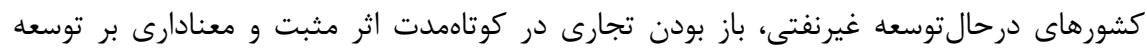

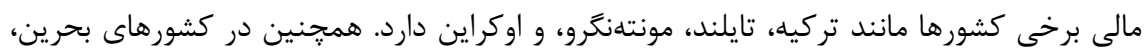

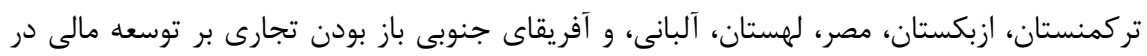

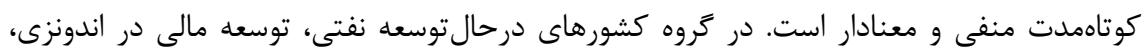

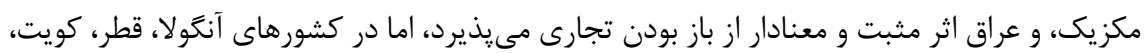

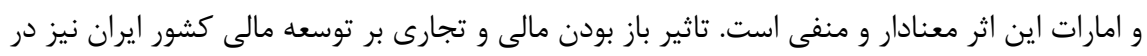

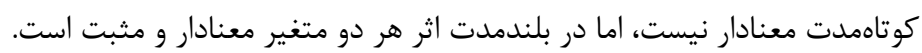

اثرهاى كوتاهمدت و بلندمدت باز بودن مالى و باز بودن تجارى بر توسعه مالى به تفكيك بخشى با توجه به كلى بودن مفهوم توسعه مالى در كشورها، در اين بخش تلاش مىشود كه اثرهاى

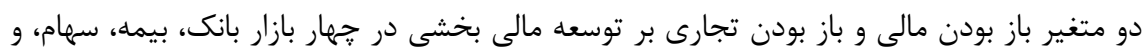

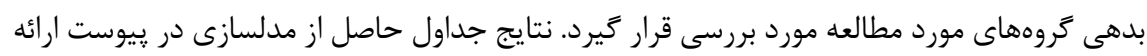
مىشود. در ادامه، خلاصه يافتههاى اين تحليلها ارائه مى مَرد مدرد.

\section{بخش بانكى}

بر اساس نتايج (نكاه كنيد به جدول بَ و إ بيوست) در كشورهاى غيرنفتى، باز بودن تجارى تاثير

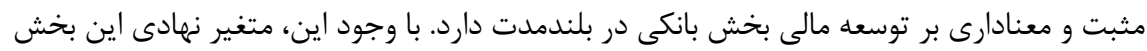

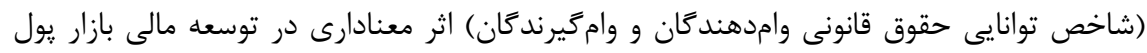

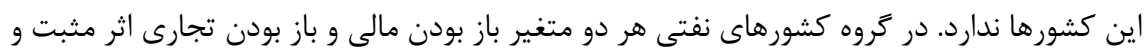

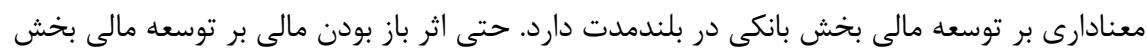


بانكى در كوتاهدت نيز معنادار و مثبت است. با وجود اين، متغير نهادى شاخص توانايى حقوق قانونى

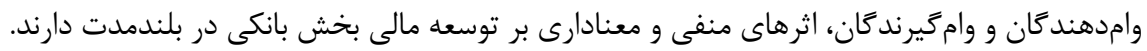
تاثير سرانه توليد ناخالص داخلى بر توسعه مالى هر دو گروه از كشورها مثبت و معنادار است. تورم نيز

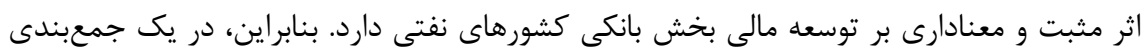

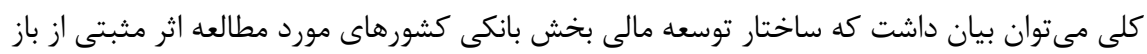
بودن تجارى مى يذيرد، اما اين كشورهاى نفتى هستند كه اثر مثبت باز بودن مالى بر توسعه بخش مانى

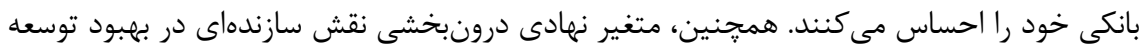

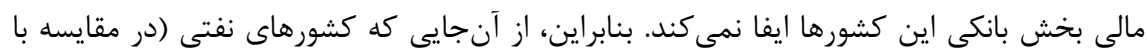

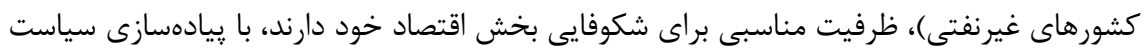
باز بودن اقتصادى (شامل باز بودن مالى و تجارى)، مىتوانند زمينههاى بهبود توسعه مالى رادر ادر اقتصاد خود فراهم سازند.

براساس نتايج (نظاه كنيد به جدول ه و و يُيوست) در كشورهاى غيرنفتى، باز بودن مالى و تجارى

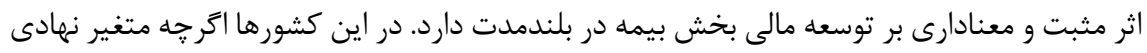

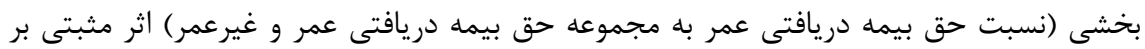
توسعه اين بخش دارد، اما اثر آن كمرنگ است. برخلاف كشورهاى غيرنفتى، باز بودن مالى اثر منفى بر توسعه مالى بخش بيمه كشورهاى نفتى در بلندمدت دارد، اما اثر باز بودن تجارى بىمعناست.

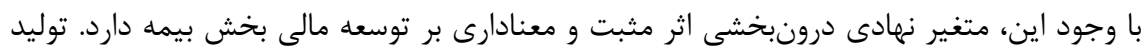

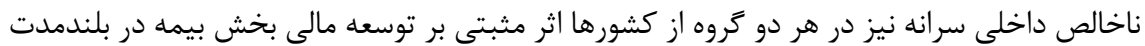
دارد. همجنين، اثر اين متغير در كشورهاى غيرنفتى كمرنگتر است. از سوى ديكر، اثر تورم بر توسعه مالى بخش بيمه در هر دو گروه از كشورها منفى است، ولى اثر آن در كشورهاى غيرنفينى

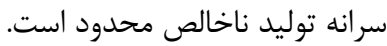


باز بودن تجارى اثر منفى بر توسعه مالى بخش بازار سهام (ارزش كل مبادلههاى بازار سهام به صورت

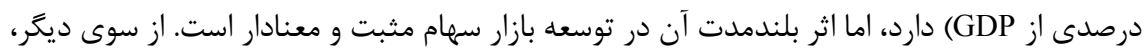

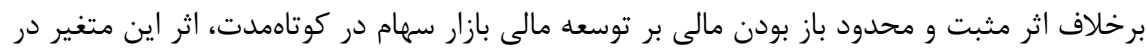
بلندمدت منفى است. با وجود اين، متغير نهادى درونبخشى (حمايت از سرمايهَذاران خرد) مىتواند

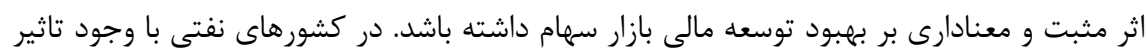
محدود باز بودن تجارى و باز بودن مالى بر توسعه بازار سهام، اثر اين دو متغير بر توسعه مالى بازار سهام در بلندمدت مثبت و معنادار است. در اين بين، متغير نهادى درونبخشى نيز اثر مثبت و

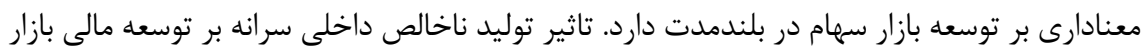

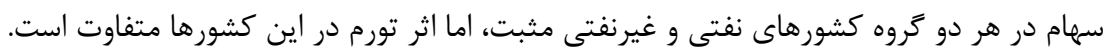

در بازار بدهى، نتايج (نكاه كنيد به جدول 9 و • • يِيوست) نشان مىدهد كه در بلندمدت تاثير

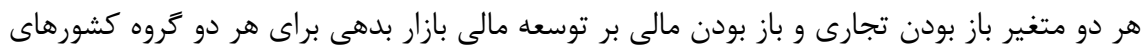
نفتى و غيرنفتى مثبت و معنادار است. تاثير كوتاهمدت و بلندمدت متغير نهادى (مقررات بازار

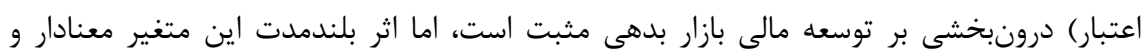

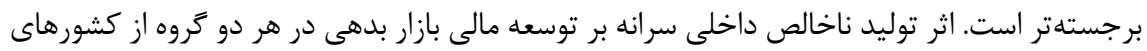

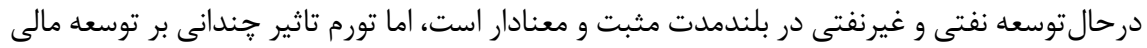
بازار بدهى در گروههاى مورد مطالعه ندارد.

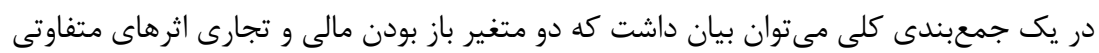

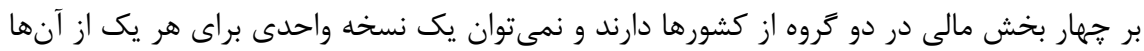
ارائه كرد. با وجود اين، در گروه كشورهاى نفتى باز بودن مالى و تجارى اثرهاى مثبت و معنادارى بر درو

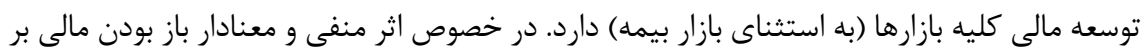

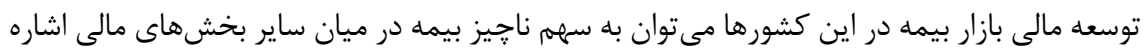

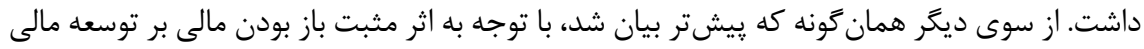
در سطح كلان اين كشورها و رشد قابلتوجه توليد در اين كشورها به صورت بديهى مىتوان مشاهده

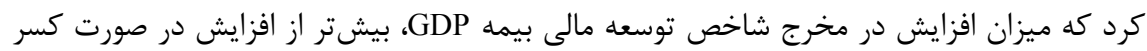

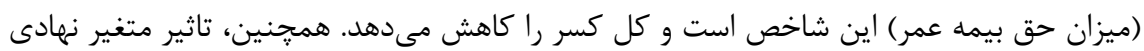




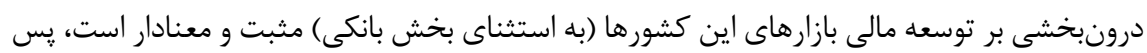

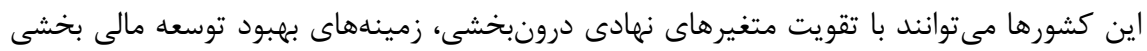

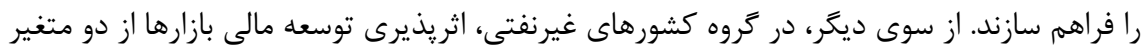

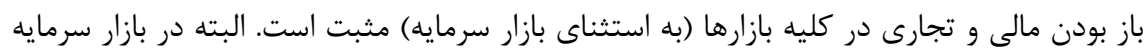

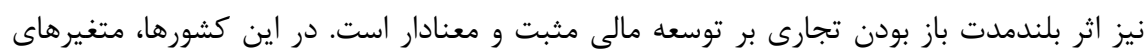

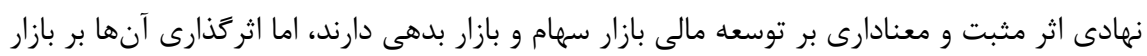
بيمه و بانك محدود است.

\section{تاثير متغير هاى نهادى فرابخشى بر توسعه مالى}

علاوه بر متغيرهاى نهادى درونبخشى، در اين يزوهش تاثير متغيرهاى نهادى فر ابخشى نيز بر توسعه

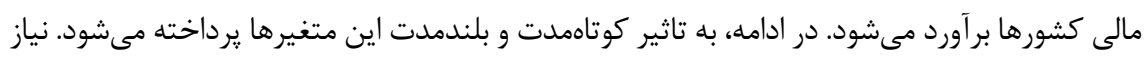

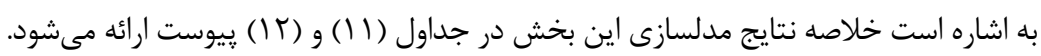

\section{شاخص حكمرانى}

نتايج بررسى اثر شاخص حكمرانى خوب بر توسعه مالى نشان مىدهد كه در بلندمدت در هر دو گروه كشورها، اثر اين متغير بر توسعه مالى معنادار نيست، ولى در كوتاهمدت حكمرانى خوب اثر

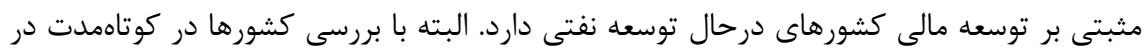

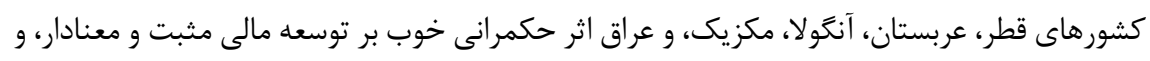

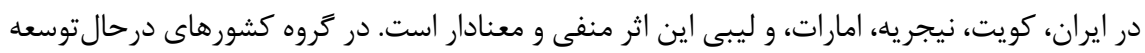

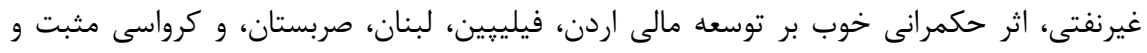

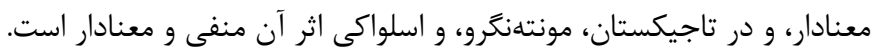

\section{شاخص حقوق مالكيت}

بر اساس شاخص حقوق مالكيت، اثر اين متغير نهادى بر توسعه مالى در كوتامددت براى كشورهاى درحالتوسعه غيرنفتى معنادار نيست، با وجود اين، اثر منفى اين متغير در بلندمدت معنادار است. با بررسى در سطح كشورى، در كوتاهمدت اثر اين متغير براى كشورهاى تركيه، تركمنستان، تاجيكستان، 
بلغارستان، لهرتان، و اوكراين مثبت و معنادار، و براى تايلند، اردن، عمان، لبنان، مجارستان، رومانى،

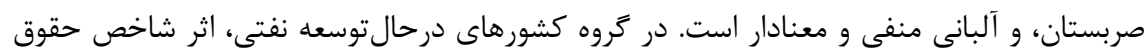
مالكيت بر توسعه مالى كشورهاى اشارهشده در كوتاهمدت و بلندمدت معنادار و مثبت است. بررسى

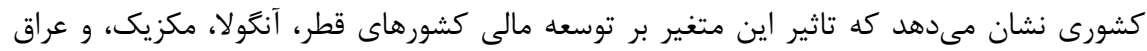
مثبت و معنادار و براى ايران، كويت، و ليبى منفى و معنادار است.

\section{اثربخشى دولت}

نتايج مدل نشان مىدهد كه اثربخشى دولت در بلندمدت در هر دو گروه كشورهاى نفتى و غيرنفتى اثرى مثبت و معنادار بر توسعه مالى دارد. اين متغير نهادى در كوتاهمدت در گروه كشورهاى درحالتوسعه غيرنفتى معنادار نيست. بررسى كشورى نشان مىدهد كه در كشورهاى اردن، لبنان،

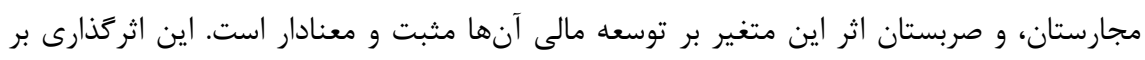
توسعه مالى كشورهاى تركيه، تاجيكستان، لهستان، اوكراين، و اسلواكى معنادار و منفى است. در مر مروه كشورهاى نفتى نيز اثر اين متغير در كوتاهمدت منفى و معنادار است. باوجود اين در كشورهاى ايران، الجزاير، كويت، و مكزيك اثربخشى دولت با توسعه مالى رابطه معنادار و مثبت دارد، ولى اثر اين متغير بر توسعه مالى كشورهاى قطر، آنكولا، اندونزى، كابن، و ليبى معنادار و منفى است. اين توضيح نياز

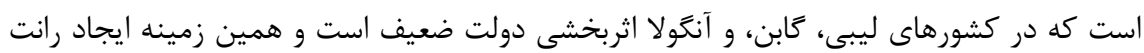
براى بخش خصوصى را فراهم مى كند كه نتيجه آن افزايش وامهاى بد است كه صورت كسر متغير

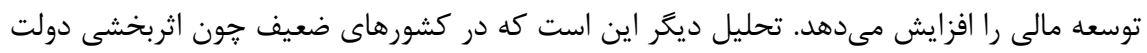
ضعيف است، GDP كاهش و در نتيجه كل كسر افزايش مى يابد. در خصوص قطر و اندونزى مى توان

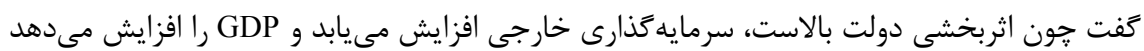

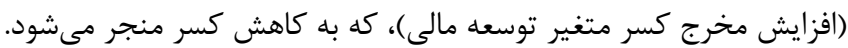

\section{ثبات سياسى}

در بلندمدت اثر ثبات سياسى بر توسعه مالى كشورهاى درحالتوسعه غيرنفتى معنادار و منفى

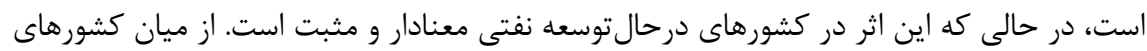
درحالتوسعه غيرنفتى، توسعه مالى در كشورهاى عمان، تاجيكستان، اسلوونى، و آفريقاى جنوبى اثر دئر درئي 
مثبت و معنادارى از ثبات سياسى مى يذيرند، اين در حالى است كه اين اثر در كشورهاى تركيه، مصر،

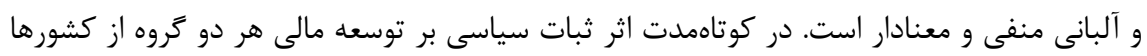

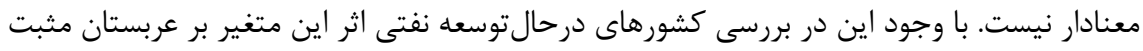
و معنادار است و بر امارات متحده عربى منفى و معنادار. زيرا كه در امارات به علت ثبات سياسى بـى

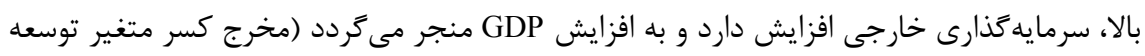
مالى)، و همين امر متغير توسعه مالى را كاهش ميىدهد. در توضيح كشورهايى كه تاثير اين متغير

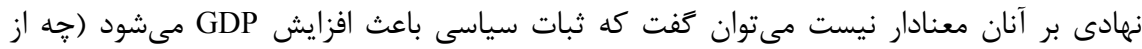

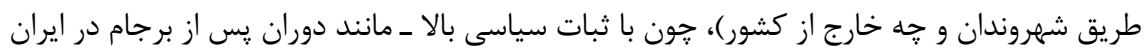

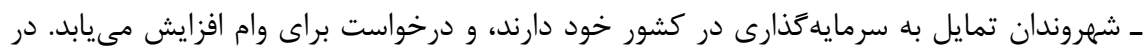
نتيجه، صورت كسر توسعه مالى (وام يرداختى به بخش خصوصى) نيز افزايش مىيابد. از طرفى GDP (مخرج كسر) نيز افزايش مى يابد كه در نتيجه، كسر متغير وابسته تغيير زيادى نمى كند.

\section{كيفيت قانونكَارى}

اثر كيفيت قانونگذارى بر توسعه مالى در بلندمدت، در كشورهاى درحالتوسعه نفتى مثبت و معنادار و در كشورهاى درحالتوسعه غيرنفتى منفى و معنادار است. در خصوص اثر كيفيت قانونكذارى دئ دئي بر توسعه مالى در كوتامدت، اين متغير نهادى بر توسعه مالى كشورهاى نفتى مثبت و معنادار است، اما اثر آن بر توسعه مالى كشورهاى غيرنفتى معنادار نيست. در بررسى كشورى مشاهده مى مَردد كه در برخى كشورهاى درحالتوسعه غيرنفتى شامل كشورهاى تركيه، تركمنستان، تاجيكستان،

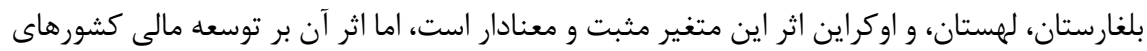

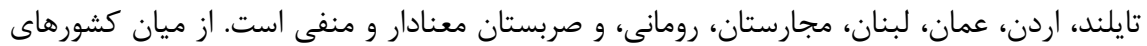

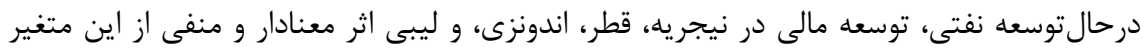

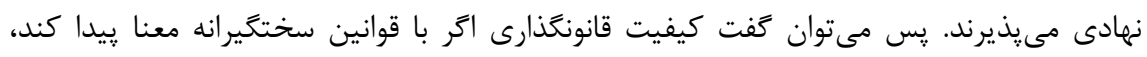
اعتبار به بخش خصوصى كاهش مىيابد و به كاهش كسر توسعه مالى منجر مىشود. استدلال ديكر

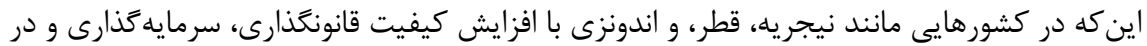
نتيجه GDP افزايش مىيابد كه كسر توسعه مالى را كاهش مىدهد. در خصوص ليبى مىتوان كفت

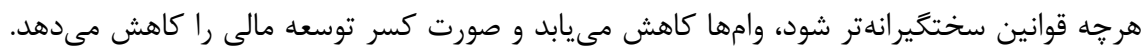
در خصوص عربستان كه اثر متغير نهادى در آن معنادار نيست، مى توان بيان داشت كه كيفيت قوانين 
GDP بسيار سختخيرانه باعث كاهش صورت كسر (اعتبار به بخش خصوصى) مىشود و كاهش مخرج نيز به ميزانى است كه كسر توسعه مالى تغيير زيادى نكند.

\section{حاكميت قانون}

در خصوص شاخص حاكميت قانون در هر دو گروه كشورها در بلندمدت هيجَّنه اثر معنادارى بر توسعه مالى مشاهده نمىشود. در كوتاهمدت نيز اثر اين متغير بر توسعه مالى كشورهاى غيرنفتى درو دره

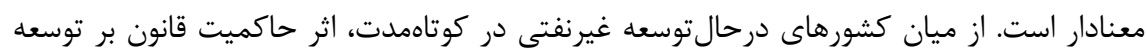
مالى در كشورهاى تاجيكستان و آفريقاى جنوبى مثبت و معنادار، و در ازبكستان و استونى منفى و و دوني

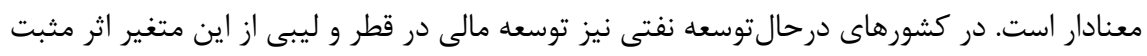

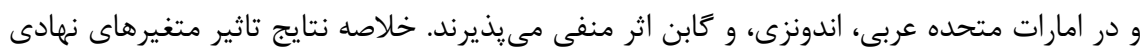

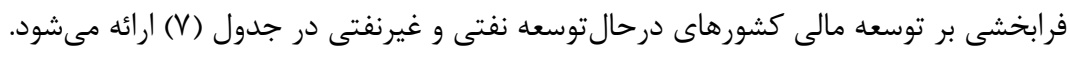

جدول Ү: خلاصه نتايج تاثير متغيرهاى نهادى فرابخشى بر توسعه مالى كشورهاى درحال توسعه نفتى و

\begin{tabular}{|c|c|c|c|}
\hline \multicolumn{4}{|c|}{ غيرنفتى } \\
\hline دوره زمانى & كشور & در حال توسعه نفتى & درحال توسعه غيرنفتى \\
\hline \multirow{6}{*}{ بلندمدت } & شاخصهاى حكمرانى & بىمعنا & بىمعنا \\
\hline & شاخص حقوق مالكيت & معنادار و مثبت & معنادار و منفى \\
\hline & اثربخشى دولت & معنادار و مثبت & معنادار و مثبت \\
\hline & ثبات سياسى & بىمعنا & معنادار و منفى \\
\hline & كيفيت قانونغَارى & معنادار و مثبت & معنادار و منفى \\
\hline & حاكميت قانون & بىمعنا & بىمعنا \\
\hline \multirow{6}{*}{ كوتاهمدت } & شاخصهاى حكمرانى & معنادار و مثبت & بىمعنا \\
\hline & شاخص حقوق مالكيت & معنادار و مثبت & بىمعنا \\
\hline & اثربخشى دولت & معنادار و منفى & بىمعنا \\
\hline & ثبات سياسى & بىمعنا & بىمعنا \\
\hline & كيفيت قانونَذارى & معنادار و مثبت & بىمعنا \\
\hline & حاكميت قانون & بىمعنا & معنادار و منفى \\
\hline
\end{tabular}




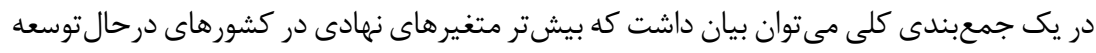

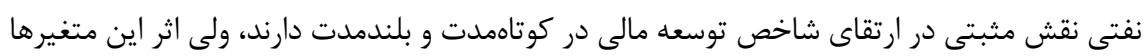

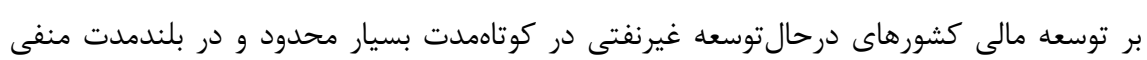

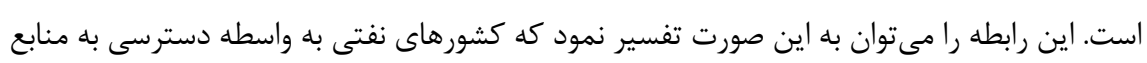

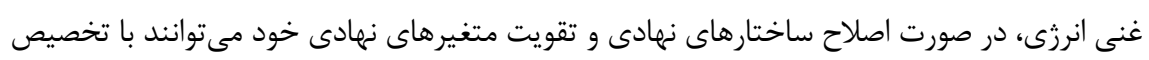

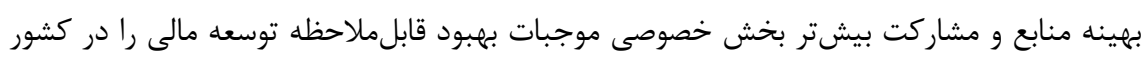

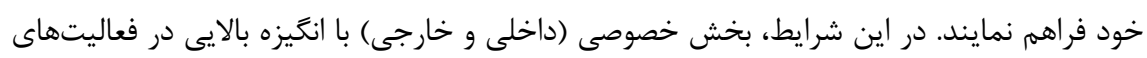

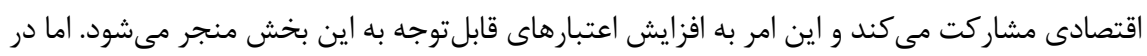

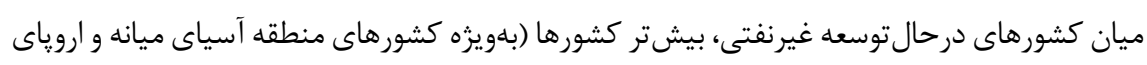

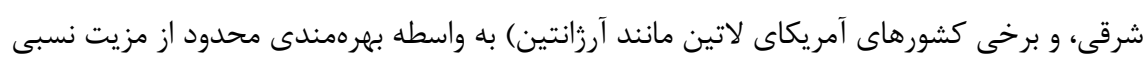

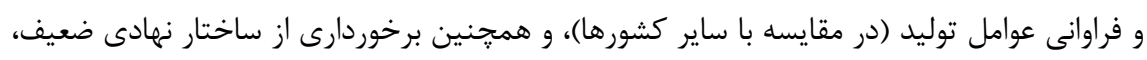

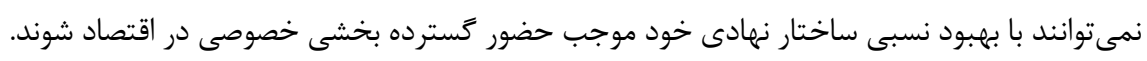

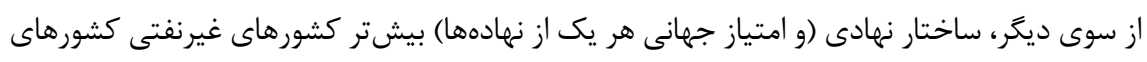

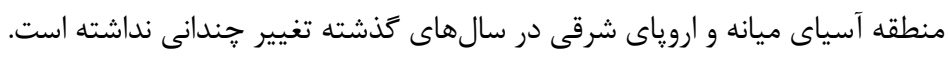

\section{بحث و نتيجه كيرى}

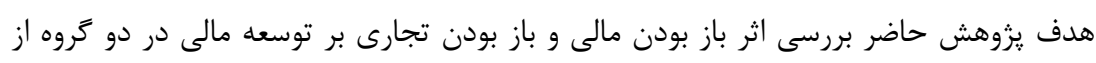

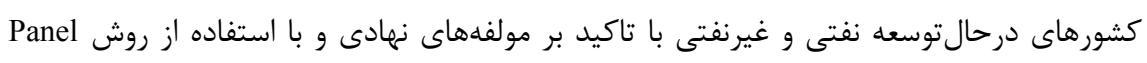

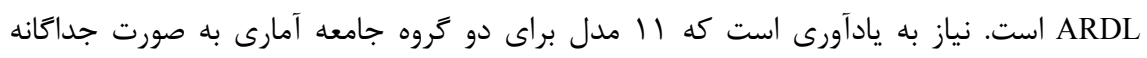

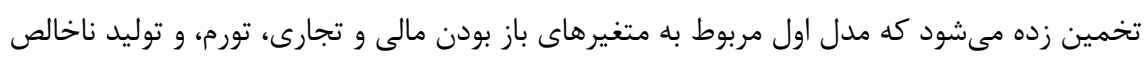

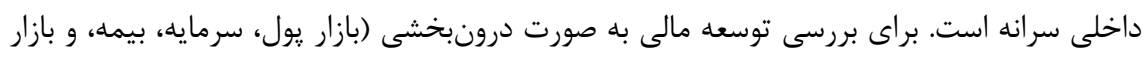

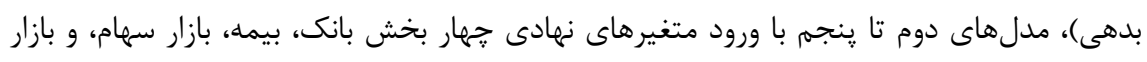

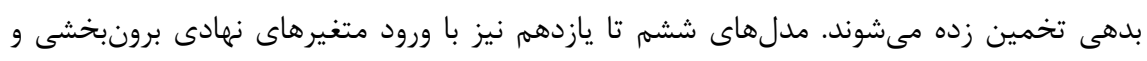

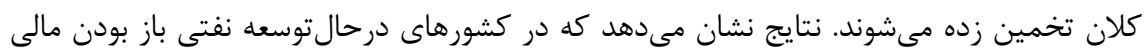

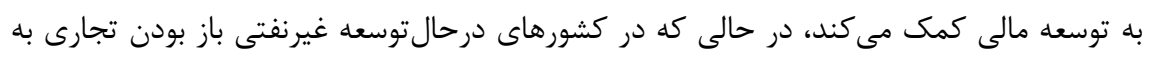
توسعه مالى كمك مى كند. 
از ميان جهار بخش بانك، بيمه، بازار سهام، و بازار بدهى مشاهده مىشود كه باز بودن مالى و تجارى در توسعه مالى بخش بانكى در كشورهاى نفتى اثر مثبت و معنادارى دارد. اين در حالى است كه اثر مثبت اين دو متغير بر توسعه مالى بخش بيمه كشورهاى غيرنفتى معنادار است. توسعه بازار سهام بهام در كشورهاى نفتى اثر معنادارى از باز بودن مالى و تجارى مى يذيرد، ولى در كشورهاى نفتى، اثرهاى

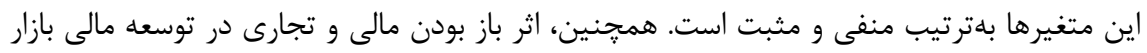

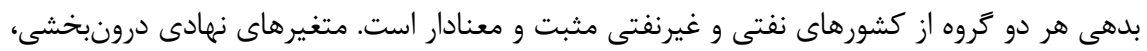

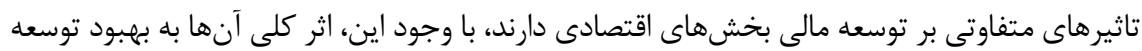

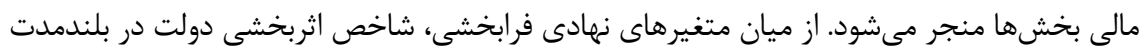

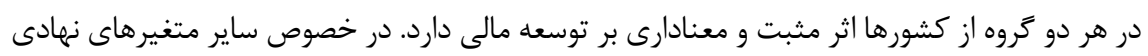

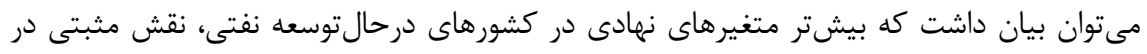

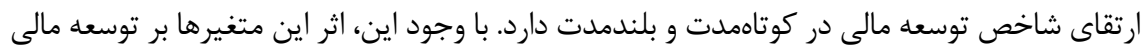

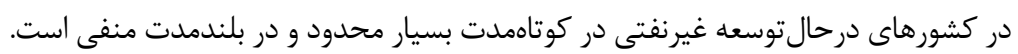

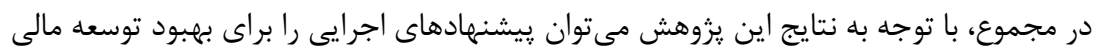
در ايران ارائه كرد. در اين رابطه، نظر به تاثير مثبت و معنادار باز بودن مالى و تجارى بر توسعه مالى لى

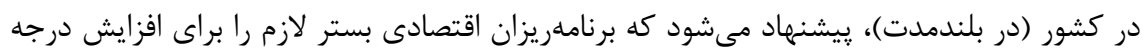

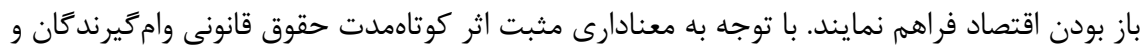
وامدهند همجنين، با توجه به اثر معنادار و مثبت متغير نهادى بيمه بر توسعه مالى بخش بيمه در ايران، مى توان در خصوص افزايش ميزان بيمه عمر و ارتقاى فرهنگ مردم در اين زمينه برنامهريزى نمود.

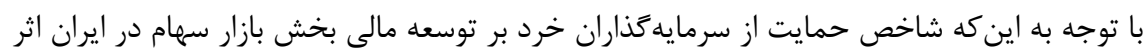
معنادار و مثبتى دارد، مىتوان براى افزايش اين شاخص برنامهريزى نمود. طبق يافتههاى يزوهش، در ايران شاخص نهادى اثربخشى دولت اثر معنادار و مثبت بر توسعه مالى دارد كه مىتوان با تقويت هرجه بيشتر اين نهاد توسعه مالى را بهبود بخشيد.

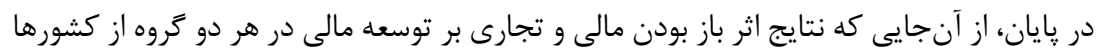

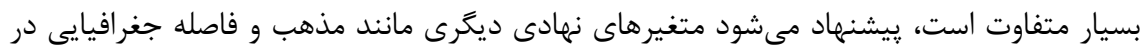

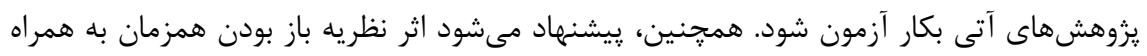




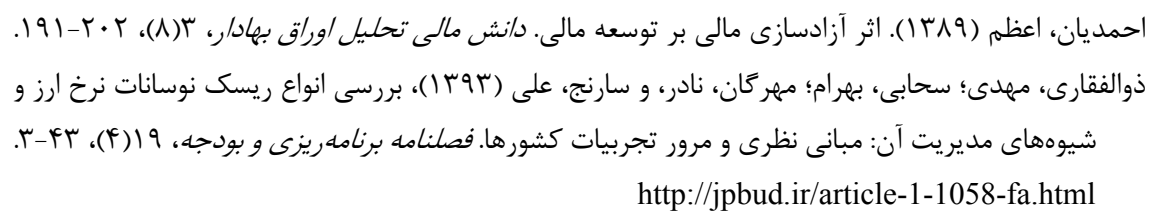

Abayomi, A., Katz, R., Spence, S., Conton, B., \& Gevao, S. M. (2016). Managing Dangerous Pathogens: Challenges in the Wake of the Recent West African Ebola Outbreak. Global Security: Health, Science and Policy, 1(1), 51-57. https://doi.org/10.108023779497.20/ 16.1228431 .

Anwar, S., Shahzadi, H., \& Nasreen, S. (2018). Determinants of Financial Development for Selected SAARC Countries: A Panel Data Analysis. Journal of Applied Environmental and Biological Sciences, 7(7), 109-118.

Asghar, N., \& Hussain, Z. (2014). Financial Development, Trade Openness and Economic Growth in Developing Countries: Recent Evidence from Panel Data. Pakistan Economic and Social Review, 52(2), 99-126.

Ashraf, B. N. (2018). Do Trade and Financial Openness Matter for Financial Development? Bank-Level Evidence from Emerging Market Economies. Research in International Business and Finance, 44(1), 434-458. https://doi.org/10.1016/j.ribaf.2017.07.115. 
and Financial Development in Sub-Sahara Africa (SSA). In International Conference on International Trade and Investment (ICITI).

Balgati, B., Demetriades, P., \& Law, S. (2007). Financial Development, Openness and Institutions: Evidence from Panel Data. World Economy and Finance Research Programme, Working Paper Series, WEF0022.

Baltagi, B. H., Demetriades, P. O., \& Law, S. H. (2009). Financial Development and Openness: Evidence from Panel Data. Journal of Development Economics, 89(2), 285-.296 https://doi.org/10.1016/j.jdeveco.2008.06.006.

Beck, T., Demirgüç-Kunt, A., \& Levine, R. (2001). Legal Theories of Financial Development. Oxford Review of Economic Policy, 17(4), 483-501. https://doi. org/10.1093/oxrep/17.4.483.

Blackburne III, E. F., \& Frank, M. W. (2007). Estimation of Nonstationary Heterogeneous Panels. The Stata Journal, 7(2), 197208-. https://doi.org/10.11771536867/X0700700204

Chinn, M. D., \& Ito, H. (2006). What Matters for Financial Development? Capital Controls, Institutions, and Interactions. Journal of Development Economics, 81(1), 163-.192 https://doi.org/10.1016/j.jdeveco.2005.05.010.

Choong, C.-K., \& Chan, S.-G. (2011). Financial Development and Economic Growth: A Review. African Journal of Business Management, 5(6), 2017-2027.

Do, Q.-T., \& Levchenko, A. A. (2004). Trade and Financial Development: The World Bank.

Ersoy, İ. (2011). The Impact of Financial Openness on Financial Development, Growth and Volatility in Turkey: Evidence from the ARDL Bounds Tests. Economic Research-Ekonomska istraživanja, 24(3), 33-44. https://doi.org/10.1080133167/ 7X.2011.11517466.

Goyal, R., Creane, S., Mobarak, A. M., \& Sab, R. (2004). Financial Sector Development in the Middle East and North Africa (Vol. 4): International Monetary Fund.

Hauner, D., \& Prati, A. (2008). Openness and Domestic Financial Liberalization: Which Comes First? Paper Presented at the Preliminary Draft, Presented at the IMF Conference "On the Causes and Consequences of Structural Reforms" Washington DC, February.

Hauner, D., Prati, A., \& Bircan, C. (2013). The Interest Group Theory of Financial Development: Evidence from Regulation. Journal of Banking \& Finance, 37(3), 895906. https://doi.org/10.1016/j.jbankfin.2012.10.008.

Kim, D. H., Lin, S. C., \& Suen, Y. B. (2010). Are Financial Development and Trade Openness Complements or Substitutes? Southern Economic Journal, 76(3), 827-845. https://doi.org/10.4284/sej.2010.76.3.827.

Kose, M. A., Prasad, E. S., \& Taylor, A. D. (2009). Thresholds in the Process of International Financial Integration: The World Bank.

Kose, M. A., Prasad, E., Rogoff, K., \& Wei, S.-J. (2010). Financial Globalization and Economic Policies Handbook of Development Economics (Vol. 5, pp. 4283-4359): Elsevier. https://doi.org/10.1016/B9783-2.00003-52944-444-0.

Law, S. H. (2009). Trade Openness, Capital Flows and Financial Development in Developing Economies. International Economic Journal, 23(3), 409426-. https://doi. org/10.1080/10168730903268398.

Levine, R. (2001). International Financial Liberalization and Economic Growth. Review of International Economics, 9(4), 688702-. https://doi.org/10.1111/9396.00307-1467. 
Levine, R. (2005). Finance and Growth: Theory and Evidence. Handbook of Economic Growth, 1(1), 865934-. https://doi.org/10.1016/S1574-9-01012(05)0684.

Menyah, K., Nazlioglu, S., \& Wolde-Rufael, Y. (2014). Financial Development, Trade Openness and Economic Growth in African Countries: New Insights from a Panel Causality Approach. Economic Modelling, 37(1), 386394-. https://doi.org/10.1016/j. econmod.2013.11.044.

Mishkin, F. S. (2006). The Next Great Globalization: How Disadvantaged Nations Can Harness Their Financial Systems To Get Rich: Princeton University Press.

Obstfeld, M., Shambaugh, J. C., \& Taylor, A. M. (2010). Financial Stability, the Trilemma, and International Reserves. American Economic Journal: Macroeconomics, 2(2), 57-94.

Onanuga, A. T., \& Onanuga, O. T. (2016). Do Financial and Trade Openness Lead to Financial Sector Development in Nigeria? Zagreb International Review of Economics and Business, 19(2), 5768-. https://doi.org/10.1515/zireb-2016-0008.

Pesaran, M. H., \& Smith, R. (1995). Estimating Long-Run Relationships from Dynamic Heterogeneous Panels. Journal of Econometrics, 68(1), 79113-. https://doi. org/10.101601644-(94)4076-0304/F.

Pesaran, M. H., Shin, Y., \& Smith, R. P. (1997). Estimating Long-Run Relationships in Dynamic Heterogeneous Panels, DAE Working Papers Amalgamated Series 9721: University of Cambridge England.

Pesaran, M. H., Shin, Y., \& Smith, R. P. (1999). Pooled Mean Group Estimation of Dynamic Heterogeneous Panels. Journal of the American Statistical Association, 94(446), 621-634.

Prebish, R. (1996). El desarrollo económico de la América Latina y algunos de sus principales problemas. El trimestre económico, 63(249), 175-245.

Rajan, R. G., \& Zingales, L. (2003). The Great Reversals: The Politics of Financial Development in the Twentieth Century. Journal of Financial Economics, 69(1), 5.50https://doi.org/10.1016/S0304405-X(03)00125-9.

Rodrik, D., \& Subramanian, A. (2009). Why Did Financial Globalization Disappoint? IMF Staff Papers, 56(1), 112138-. https://doi.org/10.1057/imfsp.2008.29.

Satyanarayana Murthy, D., Kumar Patra, S., \& Samantaraya, A. (2014). Trade Openness, Financial Development Index and Economic Growth: Evidence from India (19712012). Journal of Financial Economic Policy, 6(4), 362.375- https://doi.org/10.1108/ JFEP-10-0056-2013.

Wahid, A. N., Shahbaz, M., \& Azim, P. (2011). Inflation and Financial Sector Correlation: The Case of Bangladesh. International Journal of Economics and Financial Issues, 1(4), $145-.152$.

Zghidi, N., \& Abida, Z. (2014). Financial Development, Trade Openness and Economic Growth in North African Countries. Romanian Economic Journal, 17(53), 91-120.

Zhang, C., Zhu, Y., \& Lu, Z. (2015). Trade Openness, Financial Openness, and Financial Development in China. Journal of International Money and Finance, 59(1), 287-309. https://doi.org/10.1016/j.jimonfin.2015.07.010. 
بيوست: جداول مربوط به نتايج تخمين مدلها جدول اب: اثر كوتاهمدت و بلندمدت باز بودن مالى و باز بودن تجارى بر توسعه مالى كشورهاى

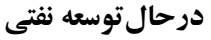

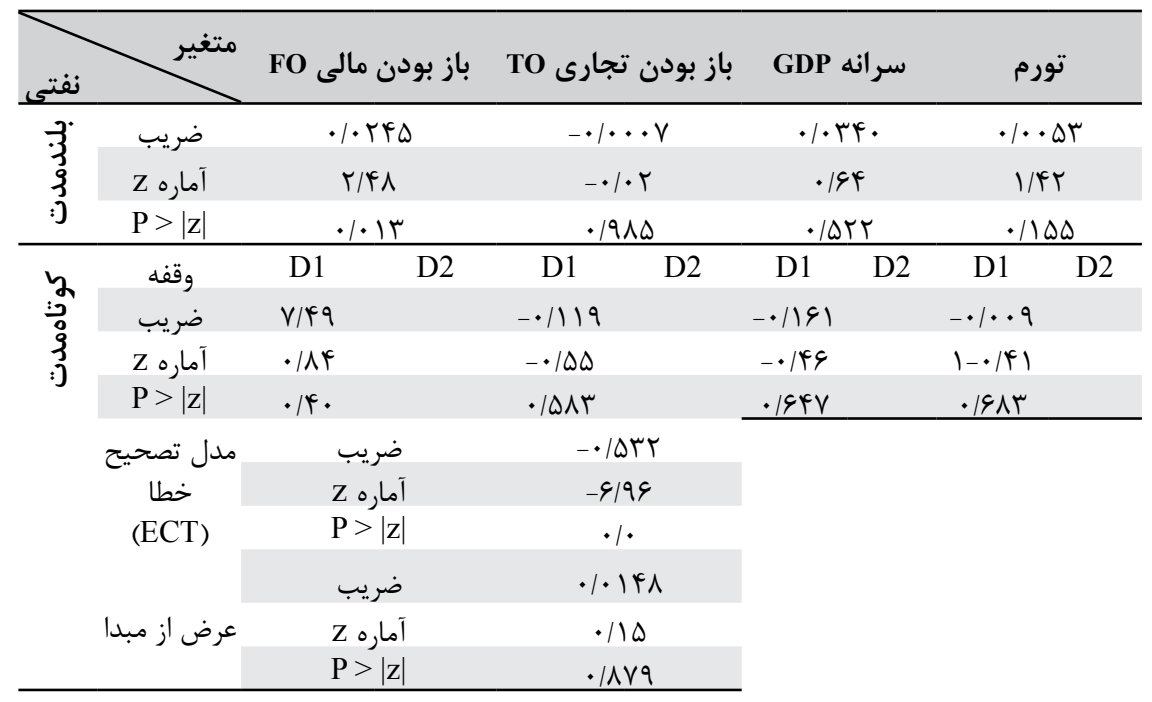

جدول rاب: اثر كوتاهمدت و بلندمدت باز بودن مالى و باز بودن تجارى بر توسعه مالى كثورهاى

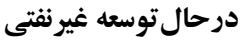

\begin{tabular}{|c|c|c|c|c|c|c|}
\hline رنفتح & 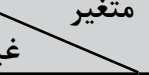 & باز بودن مالى FO & TO باز بودن تجارى & سرانه GDP & \multicolumn{2}{|c|}{ تورم } \\
\hline \multirow{3}{*}{$\begin{array}{l}3.3 \\
3.3 \\
3\end{array}$} & ضريب & -.1 .19 & $\cdot / 1 \cdot \Delta$ & .1119 & \multicolumn{2}{|c|}{$-\cdot / \cdot r r$} \\
\hline & آماره Z & $-r / \cdot V$ & $r / 99$ & $r / \Delta V$ & \multicolumn{2}{|c|}{.$- / 9 V$} \\
\hline & $\mathrm{P}>|\mathrm{z}|$ &.$/ . r q$ &.$/ . r$ & .1. & \multicolumn{2}{|c|}{ וזr/. } \\
\hline \multirow{4}{*}{$\begin{array}{l}3 \\
3 \\
\vdots \\
\vdots \\
3 \\
\vdots \\
j\end{array}$} & وقفه & $\begin{array}{ll}\mathrm{D} 1 & \mathrm{D} 2\end{array}$ & $\begin{array}{ll}\mathrm{D} 1 & \mathrm{D} 2\end{array}$ & $\begin{array}{ll}\mathrm{D} 1 & \mathrm{D} 2\end{array}$ & D1 & D2 \\
\hline & ضريب & $4 / .91$ & $-\cdot \pi r$ & $-.1 . \Delta F$ & & -.1 .04 \\
\hline & آماره Z & $1 / 48$ & $-T / \cdot D$ & $-\cdot \pi \Delta$ & & $-\cdot 109$ \\
\hline & $\mathrm{P}>|\mathrm{z}|$ & $\cdot \pi \cdot 1$ & . .4. & $\cdot / \mathrm{A} \cdot \mathrm{T}$ & & $\cdot \mid \Delta \Delta V$ \\
\hline \multirow{4}{*}{\multicolumn{2}{|c|}{ مدل تصحيح }} & ضريب & -.1948 & & & \\
\hline & & Z أماره & $-9 / \cdot 1$ & & & \\
\hline & & $P>|z|$ &. & & & \\
\hline & & ضريب & $\cdot 1 \cdot 19$ & & & \\
\hline \multirow{2}{*}{\multicolumn{2}{|c|}{ عرض از مبدا }} & z آماره & $r / 9 \Delta$ & & & \\
\hline & & $P>|z|$ &...$r$ & & & \\
\hline
\end{tabular}


جدول باٍ: اثر كوتاهمدت و بلندمدت باز بودن مالى و باز بودن تجارى بر توسعه مالى بخش بانكى كشورهاى درحال توسعه غيرنفتى باز بودن تجان

\begin{tabular}{cccccccc}
\hline متغير نهادى \\
(F)
\end{tabular}

مدل تصحيح ضريب - . lats

خطا آماره Z $-1 / 19$

(ECT)

$\mathrm{P}>|\mathrm{z}|$ $\cdot 1 \cdot$

\begin{tabular}{|c|c|c|}
\hline \multirow[t]{2}{*}{ عرض از مبدا } & Z آماره Z & $-\cdot|V|$ \\
\hline & $\mathrm{P}>|\mathrm{z}|$ & $\cdot \mid\{\wedge \mid$ \\
\hline
\end{tabular}

جدول وب: اثر كوتاهمدت و بلندمدت باز بودن مالى و باز بودن تجارى بر توسعه مالى بخش بانكى

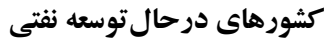

\begin{tabular}{|c|c|c|c|c|c|c|c|}
\hline نفتى & تغير & & باز بو & 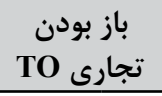 & سرانه GDP & تورم & $\begin{array}{c}\text { متغير نهادى) } \\
\text { (بانك) }\end{array}$ \\
\hline \multirow{3}{*}{$\begin{array}{l}3 \\
3 \\
3 \\
3\end{array}$} & ضريب & \multicolumn{2}{|c|}{$\cdot / r \Delta \Delta$} & $1 / r \mid 1$ & $\cdot \mid \Delta F$ & זr/. &.$- \mid G F \Delta$ \\
\hline & Z آماره Z & \multicolumn{2}{|c|}{ 1/9 } & $1 / 94$ & $1 / V 1$ & $l / A F$ & $-I / V Y$ \\
\hline & $\mathrm{P}>|\mathrm{z}|$ & \multicolumn{2}{|c|}{$\cdot / 1 \cdot \Delta$} & . & .1 .91 & .1 .94 & $\cdot 1 \cdot \wedge \Delta$ \\
\hline \multirow{4}{*}{$\begin{array}{l}2 \\
\vdots 3 \\
\vdots \\
\vdots \\
j \\
\vdots j\end{array}$} & وقفه & D1 & D2 & D1 D2 & D1 & D1 $\quad$ D2 & D1 $\quad$ D2 \\
\hline & ضريب &.$- / 1$. & $1 / 19$ & $\cdot 1 \cdot r \cdot 1$ & . & .1 .194 & $-\cdot / K F \Delta$ \\
\hline & Z آماره Z & $-1 / 91$ & $1 / v 9$ & $1 / \% \Lambda$ & $\cdot \mid \Delta \Delta$ & $1 / \cdot$ & -.19 \\
\hline & $P>|z|$ & $.1 \cdot F V$ & $\cdot 1 \cdot v F$ & $\cdot / \pi$. & $\cdot 1 \Delta \vee q$ &.$/ 119$ & 更 \\
\hline
\end{tabular}

\begin{tabular}{|c|c|c|}
\hline \multirow{3}{*}{ مدل تصحيح } & ضريب & $-\cdot / \pi r$ \\
\hline & آماره Z & $-\Delta / r)$ \\
\hline & $P>|z|$ & $.1 .1 \mathrm{~V}$ \\
\hline \multirow{3}{*}{ عرض از مبدا } & ضريب & .1 .91 \\
\hline & Z آماره & $1 / 1$. \\
\hline & $\mathrm{P}>|\mathrm{z}|$ &.$/ T V K$ \\
\hline
\end{tabular}


جدول ها: اثر كوتاهمدت و بلندمدت باز بودن مالى و باز بودن تجارى بر توسعه مالى بخش بيمه كشورهاى درحال توسعه غيرنفتى باز بونى

\begin{tabular}{|c|c|c|c|c|c|c|c|}
\hline غيرنفتى & نير & & باز بود & $\begin{array}{c}\text { تجاز بود TO } \\
\text { TO }\end{array}$ & سرانه GDP & تورم & $\begin{array}{c}\text { (بانكير نهادى) } \\
\text { متغادي }\end{array}$ \\
\hline \multirow{3}{*}{$\begin{array}{l}3 \\
3 \\
3 \\
3 \\
: j\end{array}$} & ضريب & \multicolumn{2}{|c|}{.$/ \cdot T V$} & $\cdot / r \cdot 4$ & $.1 \cdot 11$ & $-\cdot / \cdot \cdot r$ & 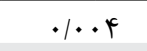 \\
\hline & Z آماره Z & \multicolumn{2}{|c|}{$F / T$} & V/AS & .19. & $-.19 V$ & T/T \\
\hline & $\mathrm{P}>|\mathrm{z}|$ & \multicolumn{2}{|c|}{.1.} &.$\%$ & $.1 \Delta \Delta$ & $.10 \ldots$ &.$/ T Y$. \\
\hline \multirow{4}{*}{$\begin{array}{l}y \\
\vdots \\
\vdots \\
\vdots \\
3 \\
\vdots j\end{array}$} & وقفه & D1 & D2 & D1 & D1 $\quad$ D2 & D1 & $\begin{array}{ll}\text { D1 } & \text { D2 }\end{array}$ \\
\hline & ضريب & & 110 &.$- / \cdot r f$ & $-\cdot / T \Delta S$ & .1 .19 & - TYY \\
\hline & Z آماره Z & & $1 / \cdot r$ &.$- / 1 f^{\mathrm{F}}$ & $-\cdot \mid \Delta V$ & $1 / \cdot F$ & $-\cdot / r \Lambda$ \\
\hline & $P>|z|$ & & . & - IANV &.$|\Delta V|$ &.$/ r q \vee$ & ./VAr \\
\hline
\end{tabular}

\begin{tabular}{|c|c|c|}
\hline مدل تصحيح & ضريب & $-\cdot 11 \cdot V$ \\
\hline خطا & آماره Z & $-1 / V 1$ \\
\hline$(\mathrm{ECT})$ & $\mathrm{P}>|\mathrm{z}|$ & .1 \\
\hline & ضريب & -.1194 \\
\hline ض & آماره Z & -.1 .9 \\
\hline & $\mathrm{P}>|\mathrm{z}|$ & $.19 \Delta r$ \\
\hline
\end{tabular}

جدول وپ: اثر كوتاهمدت و بلندمدت باز بودن مالى و باز بودن تجارى بر توسعه مالى بخش بيمه كشورهاى درحال توسعه نفتى

\begin{tabular}{|c|c|c|c|c|c|c|c|}
\hline نفتي & غير & إلى & باز بود & 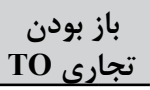 & سرانه GDP & تورم & $\begin{array}{c}\text { متغير نهادى) } \\
\text { (بانى) }\end{array}$ \\
\hline \multirow{3}{*}{$\begin{array}{l}3 \\
3 \\
3 \\
3\end{array}$} & ضريب & \multicolumn{2}{|c|}{$-\cdot \mid \cdot f 11$} & זr.•••- & - /VG & $-\cdot 1 \cdot \cdots \cdot \wedge$ & $1 / \cdot \Delta H_{1}$ \\
\hline & Z آماره Z & \multicolumn{2}{|c|}{$-r \cdot 199$} & -./Ir & rq/IV & Wr/F & אוr \\
\hline & $\mathrm{P}>|\mathrm{z}|$ & \multicolumn{2}{|c|}{.$\%$} &.$/ 9$. &.$/$ &.$/ . .1$ &.$\%$ \\
\hline \multirow{4}{*}{$\begin{array}{l}y \\
\vdots 3 \\
\vdots \\
\vdots \\
3 \\
\vdots\end{array}$} & وقفه & D1 & D2 & D1 D2 & D2 & D1 D2 & D2 \\
\hline & ضريب & $r \wedge \Delta / V$ & - IDST & سr.|. & . & $-\cdot|\cdot f| f$ & $11 T / r$ \\
\hline & آماره Z & $1 / 1$ & $-1 / \cdot V$ & Tr & .199 & -.191 & $1 / 1 T$ \\
\hline & $P>|z|$ &.$/ T V R$ & $\cdot / r \wedge \Delta$ & - /VFe &.$/ 49$ & . KTY &.$/ T G T$ \\
\hline
\end{tabular}

\begin{tabular}{|c|c|c|}
\hline \multirow{3}{*}{ مدل تصحيح } & ضريب & $-\cdot \mid \Delta r$ \\
\hline & آماره Z & $-1 / V$ \\
\hline & $\mathrm{P}>|\mathrm{z}|$ & .1 .9$. \\
\hline \multirow{3}{*}{ عرض از مبدا } & ضريب & $-Y /\{\varphi \mid$ \\
\hline & Z & $-1 / 19$ \\
\hline & $\mathrm{P}>|\mathrm{z}|$ & . IFFG \\
\hline
\end{tabular}


جدول لإ: اثر كوتاهمدت و بلندمدت باز بودن مالى و باز بودن تجارى بر توسعه مالى بازار سهام

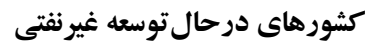

\begin{tabular}{|c|c|c|c|c|c|c|}
\hline S-l & ير & $\begin{array}{c}\text { باز بودن مالى } \\
\text { FO }\end{array}$ & 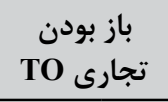 & سرانه GDP & تورم & $\begin{array}{c}\text { متغير نهادى (بانك) } \\
\text { مهاد }\end{array}$ \\
\hline \multirow{3}{*}{$\begin{array}{l}3 \\
3 \\
3 \\
\xi \\
\vdots\end{array}$} & ضريب & $-\cdot / T F$ & . /TVG & $\cdot / \pi \wedge \Delta$ & $-\cdot 1 \cdot \cdots \wedge$ & $\cdot 1 \cdot \wedge \Delta$ \\
\hline & Z آماره Z & $-9 / v 9$ & $0 / 9 T$ & $\Delta / / q$ & - & $9 / 10$ \\
\hline & $\mathrm{P}>|\mathrm{z}|$ &.$/$. & .1. &.$/$. &.$- / 119$ & .1. \\
\hline \multirow{4}{*}{$\begin{array}{l}2 \\
\vdots 3 \\
\vdots \\
\vdots \\
3 \\
\vdots\end{array}$} & وقفه & $\begin{array}{ll}\mathrm{D} 1 & \mathrm{D} 2\end{array}$ & D1 $\quad$ D2 & D1 $\quad$ D2 & $\mathrm{D} 1 \quad \mathrm{D} 2$ & D1 $\quad$ D2 \\
\hline & ضريب & זrז &.$- / 4 \varepsilon$. & $\cdot / \cdot \mu$ & .1 .14 & -110 \\
\hline & Z آماره Z & $\cdot / \wedge \Delta$ & $-T / I T$ & $\cdot \pi V$ & $1 / 1$. & $-.1 \cdot 9$ \\
\hline & $\mathrm{P}>|\mathrm{z}|$ & • & $\cdot 1 \cdot r F$ & . $/ \vee \wedge S$ &.$/ T V Y$ &.$/ 94 \Delta$ \\
\hline
\end{tabular}

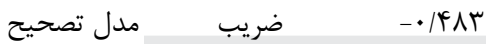

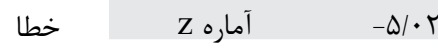

(ECT)

$$
\mathrm{P}>|\mathrm{z}|
$$

$\cdot / \cdot$

\begin{tabular}{|c|c|c|}
\hline \multirow{3}{*}{ عرض از مبدا } & ضريب & 1/9TT \\
\hline & آماره Z & $\cdot \mid 9 F$ \\
\hline & $\mathrm{P}>|\mathrm{z}|$ & $\cdot 1$ \\
\hline
\end{tabular}

جدول ^ي: اثر كوتاهمدت و بلندمدت باز بودن مالى و باز بودن تجارى بر توسعه مالى بازار سهام كشورهاى درحال توسعه نفتى

\begin{tabular}{|c|c|c|c|c|c|c|c|c|}
\hline نفت & متغير & & باز بو & تجارى & باز بودز & سرانه GDP & تورم & $\begin{array}{c}\text { متغير نهادى) } \\
\text { (بانك) }\end{array}$ \\
\hline \multirow{3}{*}{$\begin{array}{l}3 \\
3 \\
3 \\
3 \\
\vdots\end{array}$} & ضريب & \multicolumn{2}{|c|}{$.1 .94 q$} & \multicolumn{2}{|c|}{$1 / 94}$. & $1 / 091$ & $\cdot / F \wedge \Lambda$ & $.1 .9 \mathrm{~V}$ \\
\hline & آماره Z & \multicolumn{2}{|c|}{$1 / V V$} & \multicolumn{2}{|c|}{ T/TA } & $1 / 79$ & سז/ & $1 / 19$ \\
\hline & $\mathrm{P}>|\mathrm{z}|$ & \multicolumn{2}{|c|}{$\cdot / \cdot \wedge \Delta$} & \multicolumn{2}{|c|}{.$/}$. & .1191 &.$/ A F$ & .1 .91 \\
\hline \multirow{4}{*}{$\begin{array}{l}y \\
: 3 \\
\vdots \\
j \\
j \\
\vdots j\end{array}$} & وقفه & D1 & D2 & D1 & D2 & D1 & D1 & D1 \\
\hline & ضريب & $-\Delta r q$ & $I V \Delta \Delta$ & $\cdot \mid \cdot \wedge 1$ & $-1 / \cdot 1$ & $-1 / 14$ & $.1 \cdot 10$ & שחז- \\
\hline & آماره Z & س & $\mid / \pi 1$ &.$/ 1 T$ & -.191 & $-\cdot / \mu \Lambda$ & Tr/. & $-1 / \cdot$ \\
\hline & $\mathrm{P}>|\mathrm{z}|$ & . & .1191 & $\cdot / 9 \cdot 1$ & הזr/ & $\cdot / V \cdot r$ & . $/ V F \Delta$ &.$/ 419$ \\
\hline
\end{tabular}

\begin{tabular}{|c|c|c|}
\hline مدل تصحيح & ضريب & . / k fre \\
\hline \multirow{3}{*}{$\begin{array}{c}\text { خط } \\
(\mathrm{ECT})\end{array}$} & آماره Z & - M/GT \\
\hline & $\mathrm{P}>|\mathrm{z}|$ & $.1 .9 \Delta T$ \\
\hline & ضريب & $Q / \Delta F$ \\
\hline \multirow[t]{2}{*}{ عرض از مبدا } & آماره Z & $1 / 14$ \\
\hline & $P>|z|$ &.$/ T G$ \\
\hline
\end{tabular}


جدول وِ: اثر كوتاهمدت و بلندمدت باز بودن مالى و باز بودن تجارى بر توسعه مالى بازار بدهى

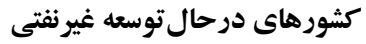

\begin{tabular}{|c|c|c|c|c|c|c|}
\hline نفتى & متغير & $\begin{array}{c}\text { باز بودن مالى } \\
\text { FO }\end{array}$ & $\begin{array}{c}\text { تاز بود } \text { TO } \\
\text { TO }\end{array}$ & سرانه GDP & تورم & $\begin{array}{c}\text { متغير نهادى) } \\
\text { (بانك) }\end{array}$ \\
\hline \multirow{3}{*}{$\begin{array}{l}3 \\
3 \\
3 \\
3 \\
\vdots 3\end{array}$} & ضريب & $\cdot 1 \cdot v V$ & .1 .09 & r./. & $\cdot 1 \cdot r r$ & $\cdot 1 \cdot 0$ \\
\hline & آماره Z & $F / F F$ & $f / \wedge q$ & $19 / 94$ & $\cdot 10$. & $r / r V$ \\
\hline & $\mathrm{P}>|\mathrm{z}|$ &.$/$. &.$/$ &.$/$ & .1919 &.$/ . .1$ \\
\hline \multirow{10}{*}{$\begin{array}{l}y \\
\vdots \\
\vdots \\
\vdots \\
\vdots \\
j\end{array}$} & وقفه & $\begin{array}{ll}\mathrm{D} 1 & \mathrm{D} 2\end{array}$ & D1 $\quad$ D2 & D1 $\quad$ D2 & D1 $\quad$ D2 & D1 \\
\hline & ضريب & -rAT & $-\cdot / V \Delta \varphi$ &.$/ T V \Delta$ & $-.1 \cdot r q$ & DrTा \\
\hline & Z آماره Z & $-1 / \cdot 9$ & $-1 / f F$ & $\cdot / 4$. & -.194 & $1 / \pi T$ \\
\hline & $P>|z|$ &.$/ r q$ & $.|| \Delta \mid$ & . & . IDTY &.$/ 119$ \\
\hline & \multirow{4}{*}{ مدل تصحيح } & ضريب & $-\cdot|F| T$ & & & \\
\hline & & Z آماره Z & $-F / A r$ & & & \\
\hline & & $\mathrm{P}>|\mathrm{z}|$ &.$/$ & & & \\
\hline & & ضريب & . $1 \cdot r s$ & & & \\
\hline & \multirow{2}{*}{ عرض از مبدا } & Z آماره Z &.$/ \cdot r$ & & & \\
\hline & & $\mathrm{P}>|\mathrm{z}|$ &.$/ 9 \mathrm{VV}$ & & & \\
\hline
\end{tabular}

جدول • إٍ: اثر كوتاهمدت و بلندمدت باز بودن مالى و باز بودن تجارى بر توسعه مالى بازار بدهى كشورهاى درحال توسعه نفتى

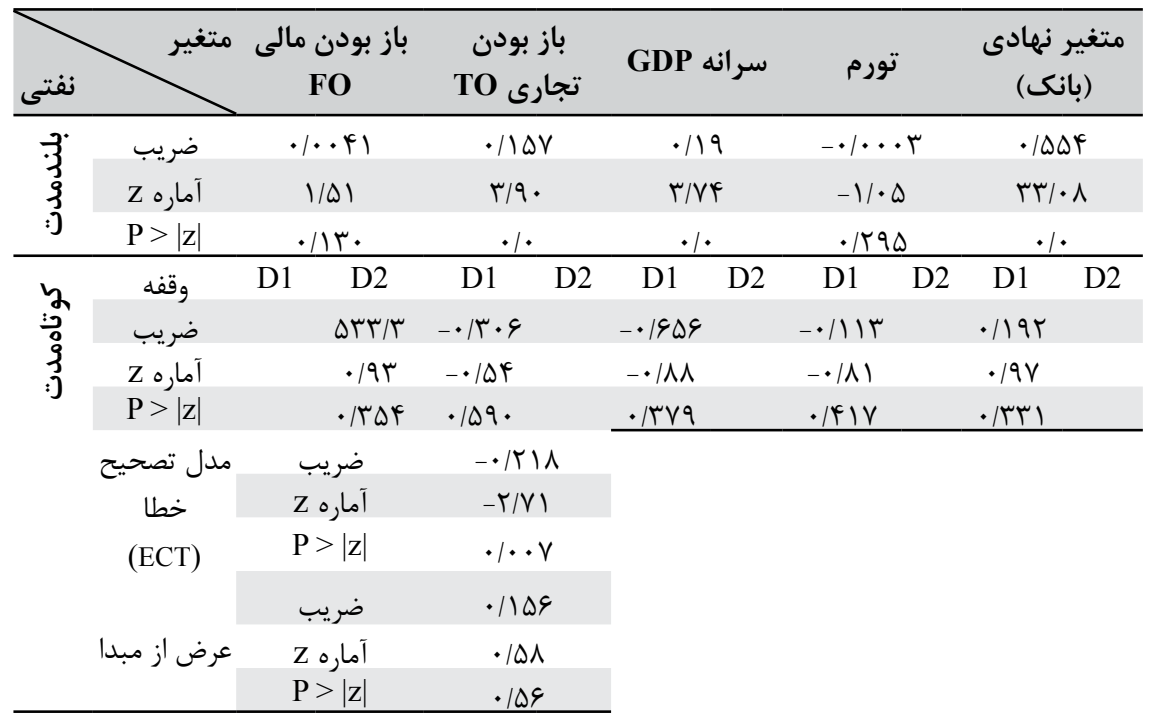




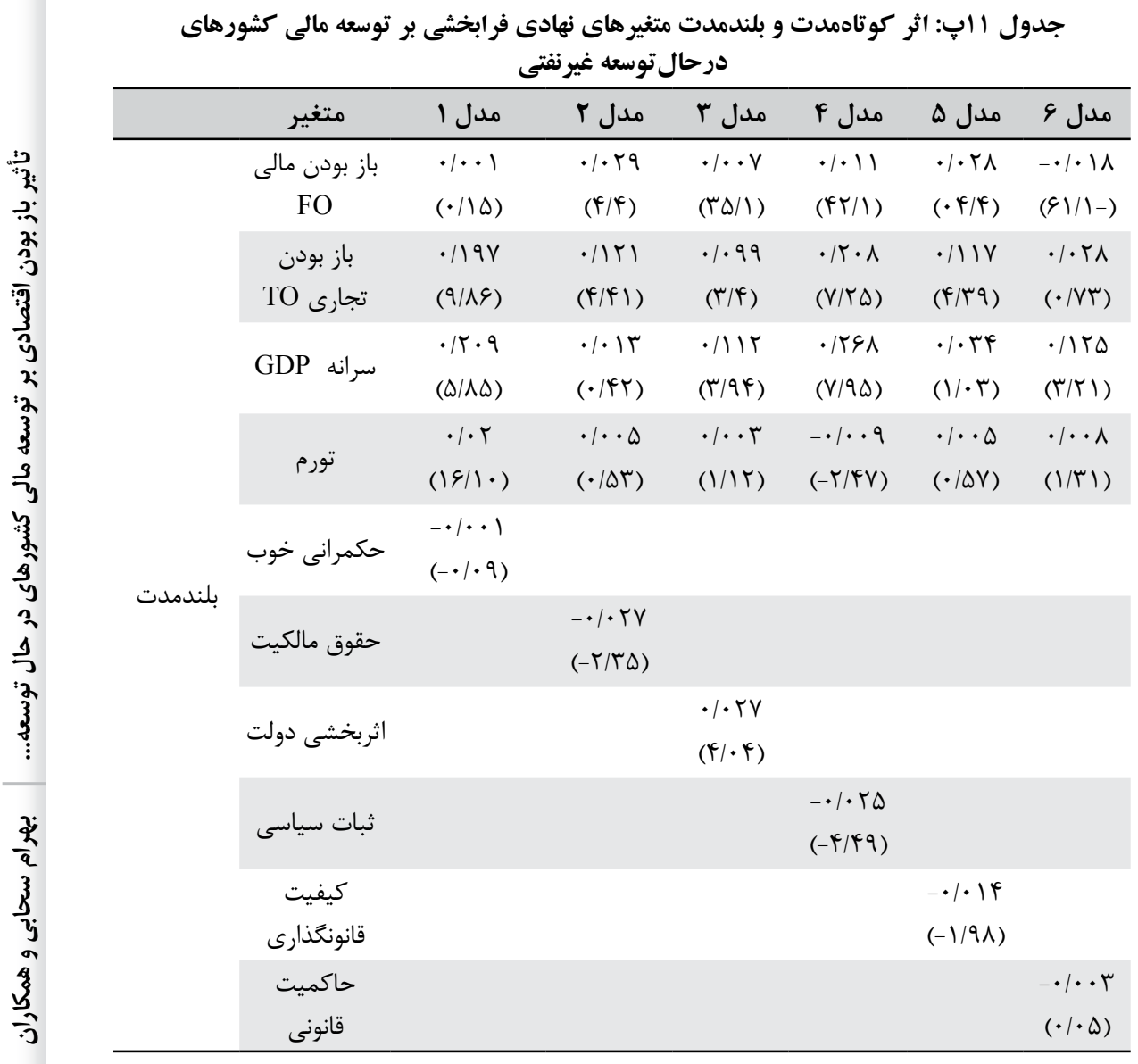




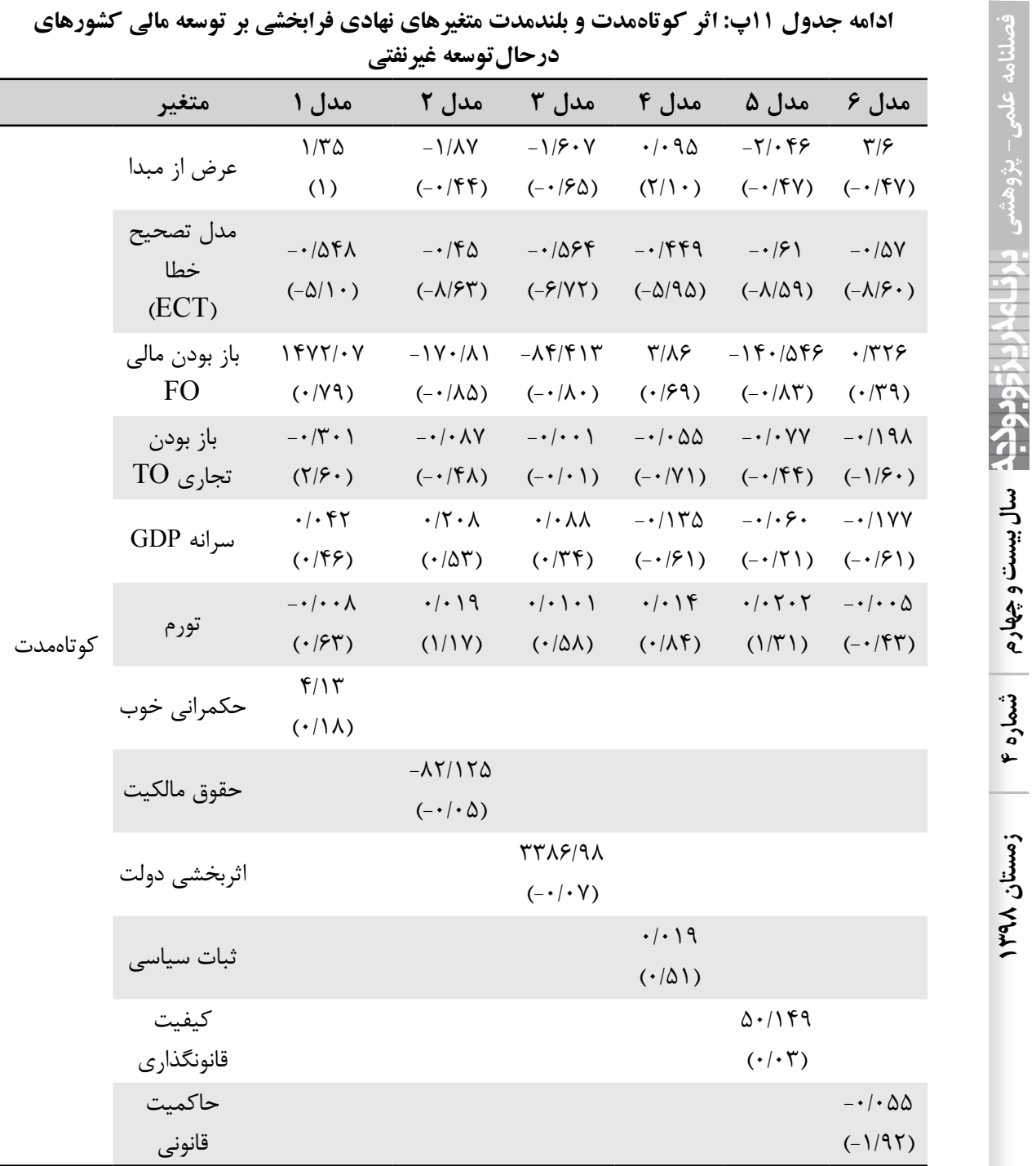

اعداد داخل برانتز، آماره Z-satistic است. 


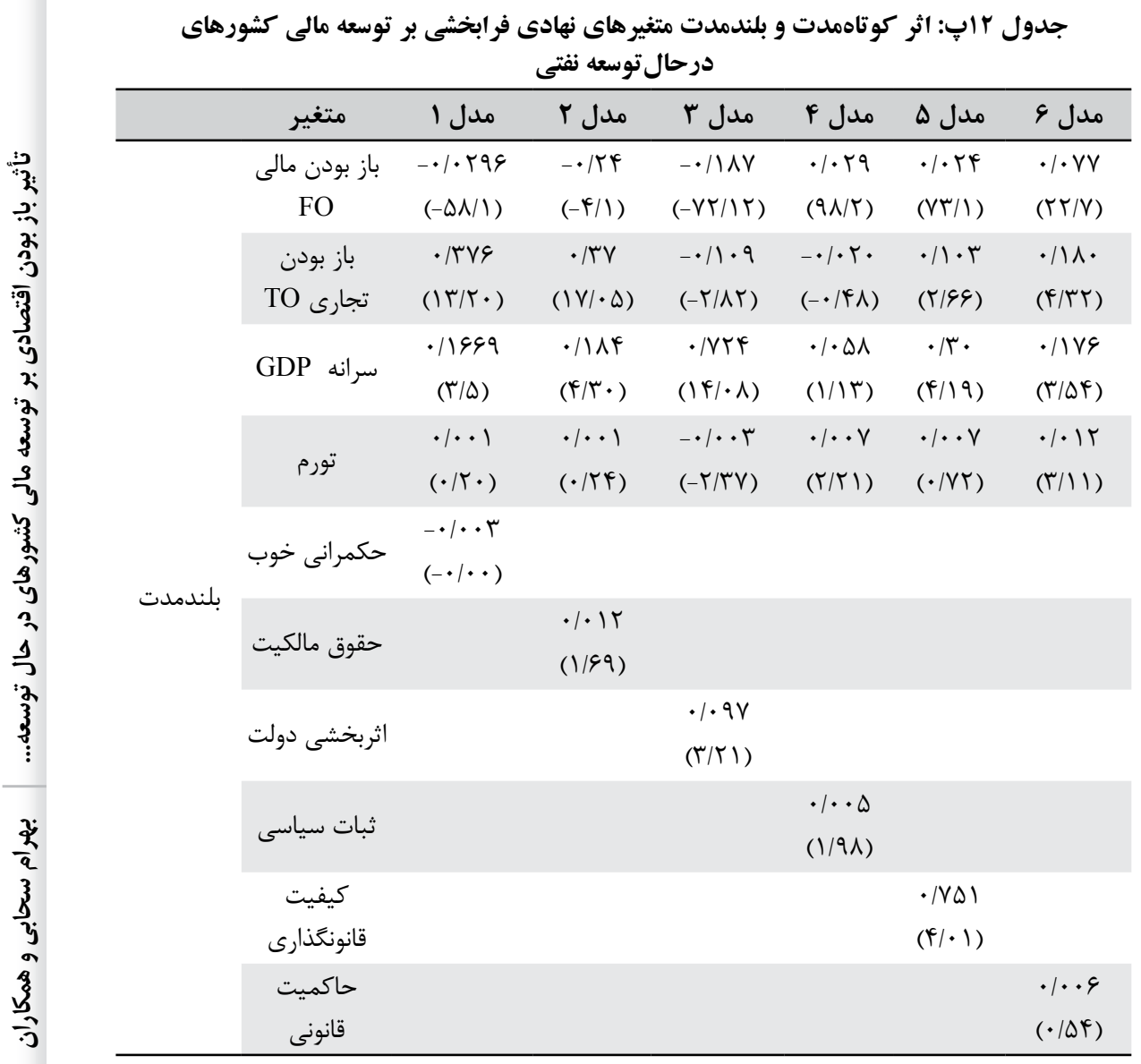


ادامه جدول rاب: اثر كوتاهمدت و بلندمدت متغير هاى نهادى فرابخشى بر توسعه مالى كشورهاى درحال توسعه نفتى

\begin{tabular}{|c|c|c|c|c|c|c|c|}
\hline & متغير & مدل & مدل r & مدل r & مدل F & مدل ه & مدل \& \\
\hline \multirow{24}{*}{ كوتاهمدت } & \multirow{2}{*}{ عرض از مبدا } & $-11 / \cdot 9$ & $-Y F / Q$ & $-Y M / 9 \Delta$ & $.1 \cdot r q$ & $-\cdot / \Delta V G$ &..$- \cdot 9 \mu$ \\
\hline & & $(-\cdot \mid \Delta Y)$ & $(-\cdot 194)$ & $(-\cdot / \Lambda)$ & $(\cdot / \pi q)$ & $(-I / A T)$ & $(-\cdot / 94)$ \\
\hline & \multirow{2}{*}{$\begin{array}{c}\text { مدل تصحيح خطا } \\
\text { (ECT) }\end{array}$} & $-1 / 1 f$ & $-1 / 194$ &.$- / 910$ & - & 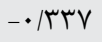 & $-\cdot / \mu \wedge$ \\
\hline & & $(-\diamond / 9 \curlywedge)$ & $(-\varphi / \Gamma \varphi)$ & $(-\varphi / \Delta \Lambda)$ & $(-9 / 9 \cdot)$ & $(-r / q \uparrow)$ & $(-\Delta / 99)$ \\
\hline & \multirow{2}{*}{$\begin{array}{c}\text { باز بودن مالى } \\
\text { FO }\end{array}$} & $9 r 1 / \cdot r$ & $\mid F T F / T$ & $r r \mid 9 / 9$ & $G \mid 9 V$ & $1199 / \pi$ & $\Lambda \Lambda \cdot / 1 \mathrm{~V}$ \\
\hline & & $(\cdot / r \varepsilon)$ & $(\cdot / \mathcal{F})$ & $(\cdot 194)$ & $(\cdot / V \&)$ & $(\cdot / V \Psi)$ & $\left(1 / \mathbb{F}^{-}\right)$ \\
\hline & \multirow{2}{*}{$\begin{array}{c}\text { باز بودن تجارى } \\
\text { TO }\end{array}$} & -.199 & $\cdot 1 \cdot 1 \cdot$ & $\cdot 109$ &.$- / .9 V$ & $\cdot 1 \cdot V V$ & $-\cdot / \pi \cdot 9$ \\
\hline & & $(-\cdot / r \Lambda)$ & $\left(\cdot / \cdot f^{f}\right)$ & $(\Gamma / M 1)$ & $(-\cdot / \mathbb{F} V)$ & $(\cdot / / \Delta)$ & $(-. / 91)$ \\
\hline & \multirow{2}{*}{ سرانه GDP } & .1981 & $\cdot / \pi 9 \Delta$ & $-\cdot / r T q$ & -.1 .91 & $-.1 .9 \Delta$ & $-\cdot / r \Delta s$ \\
\hline & & $(\cdot / 09)$ & $(\cdot / \mathcal{E V})$ & $(-\cdot / r V)$ & $(-\cdot / 19)$ & $(-\cdot / / \Delta)$ & $(-\cdot \mid 94)$ \\
\hline & \multirow[b]{2}{*}{ تورم } & .1 .19 & $\cdot / \cdot r F$ & ./.rद & $-\cdot 1 \cdot \cdot 4$ & $\cdot / \cdot r$ & $-\cdot / \cdot T \cdot$ \\
\hline & & $(\cdot / F F)$ & $(\cdot \mid \wedge f)$ & $(1 / \cdot r)$ & $(-\cdot / \cdot r)$ & $(\cdot / 19)$ & $(-\cdot / \wedge \vee)$ \\
\hline & \multirow{2}{*}{ حكمرانى خوب } & $V \Delta \Delta / \Lambda$ & & & & & \\
\hline & & $(1 / 9 \vee)$ & & & & & \\
\hline & \multirow{2}{*}{ حقوق مالكيت } & & $11 \mathrm{~V} \cdot 1 \mathrm{~A}$ & & & & \\
\hline & & & $(1 / 91)$ & & & & \\
\hline & \multirow{2}{*}{ اثربخشى دولت } & & & $-\lambda \mid k F / F$ & & & \\
\hline & & & & $(-1 / 99)$ & & & \\
\hline & \multirow{2}{*}{ ثبات سياسى } & & & & $-\cdot \cdot \cdot r$ & & \\
\hline & & & & & $(-\cdot / \mid r)$ & & \\
\hline & كيفيت & & & & & $199 / 9$ & \\
\hline & قانونَذارى & & & & & $(1 / \vee \wedge)$ & \\
\hline & \multirow{2}{*}{ حاكميت قانونى } & & & & & & $-\cdot / \cdot r \varepsilon$ \\
\hline & & & & & & & $(\cdot / / \Delta)$ \\
\hline
\end{tabular}

اعداد داخل برانتز، آماره Z-satistic - I است. 